\title{
MANU MILITARI: THE INSTITUTIONAL CONTINGENCIES OF STAKEHOLDER RELATIONSHIPS ON ENTREPRENEURIAL PERFORMANCE
}

Shon R. Hiatt

University of Southern California, shiatt@marshall.usc.edu

W. Chad Carlos

chad_carlos@byu.edu

Wesley D. Sine

Cornell University,wds4@cornell.edu

Follow this and additional works at: https://scholarsarchive.byu.edu/facpub

Part of the Business Administration, Management, and Operations Commons, and the Entrepreneurial and Small Business Operations Commons

\section{Original Publication Citation}

Hiatt, Shon R. and Carlos, W. Chad and Sine, Wesley D., Manu Militari: The Institutional Contingencies of Stakeholder Relationships on Entrepreneurial Performance (November 7, 2017). Organization Science, Forthcoming. Available at SSRN: https://ssrn.com/ abstract=2505493 or http://dx.doi.org/10.2139/ssrn.2505493

\section{BYU ScholarsArchive Citation}

Hiatt, Shon R.; Carlos, W. Chad; and Sine, Wesley D., "MANU MILITARI: THE INSTITUTIONAL CONTINGENCIES OF STAKEHOLDER RELATIONSHIPS ON ENTREPRENEURIAL PERFORMANCE" (2017). Faculty Publications. 2037.

https://scholarsarchive.byu.edu/facpub/2037

This Peer-Reviewed Article is brought to you for free and open access by BYU ScholarsArchive. It has been accepted for inclusion in Faculty Publications by an authorized administrator of BYU ScholarsArchive. For more information, please contact ellen_amatangelo@byu.edu. 


\title{
MANU MILITARI: THE INSTITUTIONAL CONTINGENCIES OF STAKEHOLDER RELATIONSHIPS ON ENTREPRENEURIAL PERFORMANCE
}

\begin{abstract}
This study examines how ventures can leverage relationships with heterogeneous government stakeholders to enhance survival in different institutional environments. We consider how the distinct resources provided from venture ties to military and political actors represent complementary strategic assets that differentially influence performance in varying political and economic environments as well as under conditions of violence and political conflict. Empirically, we examine the effect of these respective stakeholder relationships on new venture survival across 10 countries over a 65 -year period. By distinguishing between the resources obtained through relationships with different types of government stakeholders and showing how the value of these resources varies in different contexts, this study contributes to nonmarket strategy and stakeholder management research and highlights the need for studies to take a pluralistic view of government stakeholders. The paper also presents managerial insights to firms seeking to address the prevalent challenges associated with political, economic, and physical security issues in developing and underdeveloped economies.
\end{abstract}

\author{
Shon R. Hiatt \\ University of Southern California \\ shiatt@usc.edu \\ W. Chad Carlos \\ Brigham Young University \\ chad_carlos@byu.edu \\ Wesley D. Sine \\ Cornell University \\ sds4@cornell.edu
}

Forthcoming at Organization Science

\begin{abstract}
Acknowledgements
We thank senior editor Ruth Aguilera and the anonymous reviewers for their guidance, as well as Marya Besharov, Adam Cobb, Chi-Nien Chung, Glen Dowell, Lorraine Eden, Martin Gargiulo, Mauro Guillén, Daniel P. Hagedorn, Witold Henisz, Robert Hoskisson, Duane Ireland, Olga Khessina, Brandon Lee, Ben Lewis, Christopher Marquis, Noel Maurer, Aldo Musacchio, David G. Neeleman, Sangchan Park, Jordan Siegel, Michael Toffel, Pamela Tolbert, Paul Vaaler, Danqing Wang and Tyler Wry for their helpful comments. We also thank seminar participants at Brigham Young University, Cornell University, Harvard Business School, INSEAD, Melbourne Business School, National University of Singapore, Santa Clara University, University of California-Riverside, University of Hong Kong, University of Michigan, and the University of Pennsylvania. We express gratitude to Wayne Johnson and Sandy Yili Zhao for their research assistance. Lastly, we are extremely indebted to the late Ronald E. G. Davies, the Charles A. Lindbergh Chair in Aerospace History and Curator of Air Transport at the Smithsonian Institution's National Air and Space Museum, for giving us access to his data collection of world airlines, thereby making this study possible. A previous version of the paper received the 2013 Best Paper Award from the Leadership for Peace and Prosperity Conference.
\end{abstract}

\section{Funding Acknowledgements}

The authors gratefully acknowledge funding from the Ewing Marion Kauffman Foundation, the USC Lloyd Greif Center for Entrepreneurial Studies, the Cornell Institute for the Social Science, the Batten Institute for Entrepreneurship and Innovation, and the Harvard Business School Division of Research. 


\section{INTRODUCTION}

Organizations engage in nonmarket strategies to reduce environmental uncertainty and to favorably shape the environments in which they operate (Hiatt and Park 2013, Hiatt et al. 2015, McDonnell and King 2013). These strategies can take many forms but often involve collaboration with nonmarket stakeholders, such as government leaders, regulators, nongovernmental organizations, and activists (Mizruchi 1992, Lee, Hiatt and Lounsbury 2017, Armanios et al. 2017). Prior research suggests that such collaborations can benefit organizations by giving them access to resources, information, and support that can help them mitigate risk and uncertainties in the political and economic environment (Dorobantu, Kaul, and Zelner 2017). Studies have particularly focused on the benefits that accrue to organizations from relationships with government stakeholders in underdeveloped and developing countries where the rule of law is weak and where these relationships can give organizations access to important resources and insulate them from political instability (Siegel 2007, Marquis and Raynard 2015). Mostly, however, these studies have conceptualized government institutions as monolithic entities, leading to an emphasis on elected officials who grant economic and policy resources that can benefit firms. Yet, democratic governments have multiple levels that include not only the elected bodies that create policies but also the state agencies that implement and enforce them, such as regulatory agencies, the military, and police (Kalev et al. 2008). By failing to consider differences between government institutions, prior research has yet to explore the distinctive types of resources afforded by different government stakeholders and how access to these resources from business-government relationships can differentially influence organizational performance.

Recent reviews of stakeholder literature emphasize the need for research to explain how organizations can "manage the relationships with its specific stakeholder groups in an action-oriented way" (Freeman 2010, p. 53, Dorobantu, Henisz, and Nartey 2017). Understanding how firms manage relationships with different types of governmental stakeholders in different economic and political environments thus remains a critical question that has been neglected by prior studies, which have generally centered on how firms use political relationships to shape regulatory policies in their favor 
(Hillman et al. 2009, McDonnell and Werner 2016). Consequently, by focusing on the management of political uncertainty, prior research has largely overlooked how organizations may engage in strategic relationships with different state actors to mitigate other salient forms of uncertainty, such as violence and conflict.

Addressing this limitation is particularly important for organizations in underdeveloped and developing economies where threats of violence, civil unrest, crime, and terrorism are ever present (Hiatt and Sine 2014). Violence is a serious problem for businesses, hindering commercial operations by decreasing buyer demand, disrupting supply chains, and impeding international relations and investment (Czinkota et al. 2004, Oh and Oetzel 2011). Despite the prevalence of conflict in developing economies and its implications for business, existing research offers little insights for firms seeking to address such challenges (Dai et al. 2017). We address this shortcoming by investigating how new ventures in developing economies engage in strategic relationships with different types of government actors who can provide distinct resources to help manage both political and security risks. In so doing, we extend literature on stakeholder management and draw on insights from resource dependence theory to delineate the unique resources that organizations can access through relationships with political and military leaders respectively.

Accordingly, our study contributes to the growing stakeholder management literature in the following ways. First, we respond to calls for research explaining how organizations manage relationships with heterogeneous stakeholders and how the distinct resources offered by these stakeholders differentially affect organizational performance in environments with weak institutions and where the threat of violence is high (Henisz et al. 2014). More specifically, we develop deeper conceptual insights into the disparate resources supplied by different types of stakeholders, namely political and military leaders. We propose that in contrast to the policy and economic resources provided by political actors, military leaders are uniquely positioned to afford physical security and protection. Although a few recent studies have taken promising steps in considering how organizations manage relationships with multiple stakeholders, this research has generally conceptualized government ties as substitutes in that they 
represent different means to obtain similar resources (Hillman et al. 2009, Zhu and Chung 2014). We extend the conversation by examining ties with actors delivering fundamentally different types of resources that may represent complementary strategic assets (Gulati, Nohria and Zaheer 2000). Second, we investigate how the value of these distinct resources varies depending upon dimensions of the institutional environment in which the organizations operate. In so doing, we respond directly to calls for deeper insights into the contingent nature of different stakeholder relationships in varying institutional environments to further integrate stakeholder and resource dependence theory (Rowley et al. 2000).

In the following sections, we explain the conceptual differences between organizational ties to political and military actors, describe the types of resources that each stakeholder offers, and offer a baseline argument for the effects on venture survival. We then present theoretical predictions regarding the varied performance implications of these heterogeneous ties in different institutional environments. Empirically, we test our predictions using a unique data source on all venture ties to political and military leaders in the airline industry across 10 countries in Latin America over a 65-year period. We examine the impact of these relationships on survival because most ventures fail within the first few years, and because organizational survival is a precondition for profitability and growth (Aldrich and Ruef 2006).

\section{THEORY}

In contrast to the market environment that typically consists of actors such as competitors, suppliers, customers, and new entrants who engage in the exchange of property, goods, and services, the nonmarket environment is composed of broader social and political actors that may be considered external to the traditional market boundaries (Doh et al. 2012). Although market and nonmarket environments differ in terms of the actors that constitute the market and the issues and resources on which firms compete, firms engage in strategic actions to enhance performance in both environments. As prior research highlights, one common nonmarket strategy involves engaging with stakeholders who can facilitate access to resources and help create favorable operating conditions that enhance firm performance (Rowley 1997; Mair, Battilana, and Cardenas 2012). 
These forms of nonmarket strategies are rooted in stakeholder management and resource dependence theories, and they suggest that an organization relies on key resources from the environment for survival and will take strategic actions "to create for itself an environment that is better for its interests" (Pfeffer and Salancik 2003, p. 189, Wry, Cobb, and Aldrich 2013, Gargiulo 1993). A stakeholder is defined as "any group or individual who can affect or is affected by the achievement of an organization's purpose" (Freeman 2010, p. 53). Stakeholders can include a firm's investors, creditors, and employees, as well as broader community actors, such as social movement organizations, trade associations, and other parties that can influence firms through private and public political tactics such as protests, boycotts, lobbying, and lawsuits (Rao et al. 2003, Hiatt et al. 2009, Vasi and King 2012, Ingram et al. 2010, Pacheco et al. 2014; York et al. 2016). Managing relationships with stakeholders enables firms to preserve their reputation and maintain goodwill among not only their consumer base but also the broader public audience. Because these stakeholders represent resource providers and influencers, it is important for firms to maintain positive social evaluations from these actors (King and Soule 2007, Carlos and Lewis 2017).

In addition to managing relations with community stakeholders, research has placed particular emphasis on the importance of managing organizational relationships with government stakeholders (Okhamtovskiy and David 2012, Walker and Rea 2014, McDonnell and Werner 2016, Georgallis, Dowell and Durand 2017). This is particularly important for ventures operating in undeveloped and developing economies, as government relationships can supply access to government contracts, market protection, and favorable regulatory treatment (Marquis and Qian 2013, Zhang. Marquis, and Qiao 2016, Marquis and Raynard 2015, Luo, Wang, and Zhang 2017). Examples in management studies illustrate how organizations that leverage ties to political actors enjoy performance benefits, including higher market share, profitability, and stock returns (Peng and Luo 2000); access to credit (Inoue et al. 2013, Leuz and Oberholzer-Gee 2006); and government bailouts (Faccio et al. 2006).

Although work on nonmarket strategy has been fruitful in illustrating the benefits associated with firm relationships to government stakeholders, recent work highlights a critical limitation: an increasing 
number of studies indicate that these relationships may be more complex than previously theorized, whereby ties exert negligible or sometimes detrimental effects on organizations (Siegel 2007, Mellahi et al. 2016). We suggest that these discrepancies may be due in part to management scholars taking a monolithic view of government stakeholders, focusing narrowly on relationships with political officials. However, government stakeholders include not only policymakers but also those that interpret and carry out policy such as regulatory agency bureaucrats, the police, and the military (Baron, Dobbin and Jennings 1986, Hiatt and Park 2013). Despite recent efforts to more fully consider the characteristics of different types of government stakeholder relationships and their varying impact on firm outcomes (Zhu and Chung 2014), studies have largely conceptualized resources from different types of government connections as substitutes and have yet to theorize whether and under what conditions resources from different government stakeholders may represent forms of substitutes or complements.

As a result, research is limited in providing few theoretical insights into other prevalent forms of uncertainty in developing economies such as armed conflict and revolution and the types of stakeholder management strategies needed to address them. This oversight is significant given the recent work that highlights the detrimental effect of violence on firm performance (Oh and Oetzel 2011, Hiatt and Sine 2014). We address these limitations by theoretically distinguishing between relationships with political and military stakeholders and hypothesizing about how the benefits associated with the resources furnished by these different actors is contingent upon varying environmental conditions, including economic uncertainty and conflict.

\section{Heterogeneity in Governmental Stakeholders}

To date, most nonmarket strategy research on organizational ties to government stakeholders has conceptualized these ties as homogenous in terms of the resources they offer to organizations (Zhu and Chung 2014). Viewing relationships with different governmental stakeholders as substitutable resources overlooks important distinctions between different types of government actors and the unique resources they afford. Military officials differ from political officials in that they "are the immediate wards of the state's monopoly on violence" (Evans 1979, p. 49) and have greater control over critical resources related 
to physical security. The failure of prior research to explore the influence of military relations on firm outcomes is particularly surprising given the military's prominent role in providing security and acting as a backstop against chaos in developing and underdeveloped countries. For instance, in countries that experience revolutions in which radical institutional and economic changes occur, the military often becomes instrumental in restoring some order after governmental collapse (Fitch 1998). The military is also an essential source of security that protects businesses from other acts of crime or violence and gives comfort to investors (Resende-Santos 2007). For instance, in Colombia, where businesses are regularly subjected to violence (Hiatt and Sine 2014), military protection is often used to ensure ongoing business operations. As one firm executive benefiting from military assistance emphasized, "For the military, the priority is to protect and provide confidence for investors ... For the investor, it's important that he know that in Colombia he has an ally" (Forero 2004).

Although studies have discussed the vital role of military actors in wielding their power to suppress protests or insurrections in order to preserve the existing regime, or in temporarily functioning as the ruling authority (Fitch 1998), prior research has neither distinguished conceptually between the military and other government entities nor identified how organizational connections to these stakeholders may differentially affect firm performance. In the following section, we develop the conceptual differences between political and military stakeholder relationships. By so doing, we extend the stakeholder management literature, which has largely failed to consider the differential influence of various government stakeholders, and in particular the military, on organizational performance (Dorobantu, Kaul and Zelner 2017).

Relationships with Political Stakeholders. Political ties have received the most attention in prior research. Studies have highlighted the material benefits that accrue from relationships with prominent political stakeholders, including government contracts, access to information, and favorable regulatory treatment, as well as their symbolic benefits, in the form of enhancing perceptions that the firm is endorsed by the state (Bucheli and Aguilera 2010, Bucheli and Kim 2015, Musacchio and Lazzarini 2014, Musacchio, Lazzarini and Aguilera 2015). For instance, in a study of the Chilean phone company ITT- 
CTC, scholars found that political party associations of the firm's executive board members affected the degree to which Chilean policies benefited or hindered the organization (Bucheli and Salvaj 2013). In another example, a study on the United Fruit Company argued that the company's relationship with the presidential administration of Honduras was the critical factor in its ability to receive land concessions for banana production in Honduras (Bucheli 2008). Similarly, Hillman and colleagues (1999) discovered that firms experienced positive abnormal shareholder returns when they employed top managers that had been appointed to federal positions in the U.S. government. Peng and Luo (2000, p. 495) poignantly illustrate the benefits of managerial ties to government in this quote obtained from interviews with a manager who explained that friends in the government "can procure cheaper materials for you, provide priority access to infrastructure, and promote your products in state-controlled distribution channels."

Relationships with Military Stakeholders. In contrast to political ties that provide ventures access to financial and policy resources, we propose that due to the military's coercive power, the key resource that can derive from firm-military relationships is security, in the form of either physical or symbolic protection (Gambetta 1996). In developing countries, and particularly in Latin America, the threat of violence is an ever-present risk for businesses. For example, during the 1980s and 1990s, Colombian guerillas regularly kidnapped firm employees, which affected operations and engendered fear in employees and customers (Ambrus 2002). The use of military forces to protect business operations is common in countries throughout Latin America and is critical not only for protecting businesses but also for providing comfort to investors (Forero 2004). Physically, the military can furnish resources to reduce these risks by stationing troops and weaponry near businesses to which they have ties in order to provide stability and to protect personnel and firm assets. Military leaders can also offer security intelligence to businesses with which they have ties. The military has proprietary knowledge of the current and future locations of military personnel as well as data on when and where criminal activity most commonly occurs. This information can help organizations know where it is safest to do business and avoid areas where they may face attacks and extortion. Knowing where the military intends to enhance security and the rule of law can reduce growth risks in volatile environments. Symbolically, even if the military does 
not physically deploy troops or other resources in protecting businesses, those businesses with visible ties to the military may nevertheless be less likely to be targeted by criminals, for fear of military retribution.

In summary, political and military actors represent fundamentally different types of government stakeholders providing distinct resources that can enhance organizational performance. Our baseline expectation is that in developing and underdeveloped economies, organizational ties to political and military stakeholders will both enhance venture survival by giving ventures preferential access to policy and security resources. Building upon this baseline, in the next section, we further characterize the contingencies that affect the value of relationships between organizations and these two different stakeholders.

\section{INSTITITUTIONAL CONTINGENCIES AFFECTING THE VALUE OF GOVERNMENT STAKEHOLDER RELATIONSHIPS}

Given the distinct resources that political and military stakeholders can provide new ventures, we propose that the survival-enhancing benefits of relationships with these actors are likely to differ based on institutional factors that amplify or attenuate the value of the respective resources. In doing so, we respond to calls to examine the contingent nature of stakeholder relationships in institutional environments characterized by different economic and political conditions (Siegel 2007) and varying levels of violence and conflict (Oetzel and Getz 2012). We explore these contingencies by considering the following four factors that have been identified by prior stakeholder management research to influence firm performance, namely the economic environment (Rowley et al. 2000), stakeholders' political effectiveness (Henisz et al. 2014, Hiatt et al. 2015), armed conflict (Dorobantu et al. 2017), and government revolutions (Oh and Oetzel 2017). Doing so allows us to test our proposed mechanisms under these varying institutional contingencies. We propose that the economic environment and stakeholders' political effectiveness or ability to credibly enact policy will increase the benefits derived from relationships with political leaders, while critical events that threaten the physical security and operations of ventures such as armed conflict and government revolutions will amplify the benefits resulting from relationships with military leaders. 


\section{Political Relationship Contingencies}

Economic Environment. The extent to which government stakeholder relationships can benefit ventures is likely to vary according to the economic environment in which a venture operates. This moderating effect may be particularly significant for ties to political leaders that can provide material and symbolic financial resources through government policy and contracts. The ability to obtain resources is essential for venture survival, and when key resources become scarcer, strategic relationships that enhance access to resources become even more important (Rowley et al. 2000). Specifically, we argue that in countries with contracting economies, firms will benefit more from connections with political stakeholders who can help to buffer the loss in profits and provide firms with other resources. When an economy is declining, firms are likely to face operating budget shortfalls, which can threaten performance and stifle opportunities to obtain outside financing and investment (Filatotchev et al. 2000). Research on Latin American fiscal policy suggests that during economic downturns, government seigniorage and spending is likely to increase in an effort to prevent the economy from entering a prolonged recession (Roubini 1991). In such situations, political ties can benefit ventures by giving them enhanced access to government expenditures.

Political relationships not only help entrepreneurs obtain financial backing from state institutions, or secure government contracts, they can also signal credibility and legitimacy to private institutions such as banks and lenders ( $\mathrm{Li}$ et al. 2008, Faccio et al. 2006). The symbolic legitimacy afforded by relationships with political actors can be particularly relevant during times of greater economic uncertainty. When resources are scarce, competition for them intensifies, and resource providers can be more selective in the firms they support. Investors and other resource providers seeking to mitigate risk and enhance profit have more options to consider, and firms seeking their support must find ways to differentiate themselves from competitors. In this type of competitive environment, the symbolic endorsement of firms that is signaled by their relationships with government leaders can be a significant competitive advantage. Thus, the symbolism provided by venture ties to political stakeholders is particularly valuable during times of economic uncertainty because it signals a firm's legitimacy and suggests government endorsement, which 
may reduce investors' perceptions of risk associated with the firm (Stevens et al. 2016). In contrast, when economies are growing, the increasing abundance of economic resources creates more opportunities for firms to obtain resources and reduces competition for those resources, which is also likely to reduce the value of ties to political stakeholders. For these reasons, we anticipate that when economies are declining, the value of political ties for venture survival will be greater.

Hypothesis 1: Organizational ties to political stakeholders will have a greater impact in enhancing venture survival in countries experiencing a declining economic environment.

Political Effectiveness. Another factor that may differentially moderate the benefits of government stakeholder relationships is their political effectiveness, or stakeholders' ability to credibly enact or alter policy. Since military leaders are generally removed from the policymaking process, we argue that this factor will moderate the value of relationships with political leaders. Research in stakeholder management acknowledges that as the credibility of stakeholders to influence public policy in their favor increases, their power to influence firm strategy and outcomes also increases (Hoffman and Ocasio 2001, Lyon and Maxwell 2011). For instance, in the oil and gas sector, Hiatt and colleagues (2015) found that as the perceived capacity of climate-change stakeholders to alter regulation surged, petroleum companies responded to their demands by implementing carbon-sequestration technologies.

In a similar way, we argue that as the ability of stakeholders to carry out policies that can benefit ventures increases, so will the value of ventures' relationships with these stakeholders. Specifically, if political leaders have greater ability to craft, pass, and hold up or "veto" economic policy related to taxation, disbursement, commerce, and foreign policy (Tsebelis 1995), they will be more able to direct policy, payments, and government contracts to firms in their political networks. Materially, this factor should increase the value of venture ties to political stakeholders and enhance survival by giving ventures preferential access to beneficial policy. The symbolic value of relationships with political stakeholders is also likely to increase in countries where the country institutions allow for greater political effectiveness. When stakeholders are seen as credible in shaping and enacting policies, the symbolic value of firms' relationships with political leaders is enhanced in the eyes of the firms' stakeholders. In other words, the 
symbolic value of ties to government stakeholders is valued so far as audiences view the political leaders as having a real and specific impact on laws and policies that can affect the firms to which they are connected (Lipset 1959). Thus, we expect that the value of political ties in providing material and symbolic resources will be more beneficial for venture survival in countries where institutions allow political stakeholders to be more effective in exercising their power to shape and implement policies.

Hypothesis 2: Organizational ties to political stakeholders will have a greater impact in enhancing venture survival in countries where such stakeholders are more politically effective

\section{Military relationship contingencies}

Armed Conflict. We now turn to critical events that threaten the physical security and operations of ventures and suggest that these events will enhance the value of ties to military stakeholders who can grant security resources to ventures. In many developing and underdeveloped countries, organizations face criminal activity, terrorism, and guerrilla warfare, all of which can damage an organization's assets, harm its personnel, reduce its sales, and increase the risk and cost of doing business and foster firm failure (Hiatt and Sine 2014, Oh and Oetzel 2017). Conflict is not limited to terrorism and guerrilla warfare, however. Criminal activity and related violence are prevalent concerns in developing countries and pose significant risks to businesses (Dai et al. 2013, 2017). For instance, drug cartels in Mexico and Colombia extort businesses for payment; if owners refuse to pay or pay late, their businesses may be vandalized or destroyed and their employees tortured and killed (Castillo and Stevenson 2014). Other prominent examples of countries where violence negatively impacts business are Honduras and Brazil, which have some of the highest violent homicide rates in the world, due largely to drug trading. According to the Brazilian security think tank Igarapé Institute, “more people are killed every year in Brazil through intentional violence than anywhere else on the planet, including most of the world's war zones combined" 
(Nehamas and Brufatto de Oliveira 2013). ${ }^{1}$ These threats hinder business activity and ultimately survival by generating fear in employees, investors, and customers.

We propose that where armed conflict is particularly high, the resources of physical protection acquired through ties to military stakeholders will be more valuable for venture survival. Businesses with military connections may be protected from criminals, mobs, strikes, and popular uprisings "due to [the military's] privileged access to weapons and transport facilities" (Brömmelhörster and Paes 2003, p. 14). Military officers may directly assign troops to protect the assets and personnel of firms with which they have a relationship (Shemo 1996). Moreover, strong ties with coercive stakeholders help protect ventures by presenting a legitimate and credible threat of retribution (Raven and French 1958, Gambetta 1996). Finally, affiliations with the military can offer symbolic benefits by creating a reputational effect that increases the confidence of investors and creditors that the business will be protected. This can make it more likely that resource providers maintain their support during periods of conflict. We therefore argue:

Hypothesis 3: Organizational ties to military stakeholders will have a greater impact on enhancing venture survival in countries experiencing higher incidence of armed conflict.

Political Revolutions. Many underdeveloped and developing economies face severe volatility that threatens the foundations of their political institutions. At the extreme end are political revolutions, defined as forceful extraconstitutional changes to the power structure of a regime where one polity replaces another (Oetzel and Getz 2012). Revolutions can be instigated by massive population revolts, civil wars, and military coups d'état where political leaders are forced to resign, go into exile, or are assassinated, and they commonly involve "the demolition of old political institutions and the establishment of new ones" (Carroll et al. 1988, p. 367), wherein constitutional changes, suspension of rule of law, usurpation of property rights, and disruption of state operations occur (Miller 1992). For example, after the failed 2016 government coup, the Turkish president announced a three-month state of emergency that curtailed constitutional rights and enacted martial law, resulting in the firing and

\footnotetext{
${ }^{1}$ More recently, the faltering economy in Venezuela has helped thrust it near the top ranks of the world's most violent countries (Vyas 2016).
} 
suspension of 82,000 state employees (Levin and Peker 2016, BBC News 2016). Thus, revolutions can cause great risk for organizational revenue and assets.

Political volatility can reduce the value of political relationships and, in some cases, even negatively affect firms with connections to political leaders (Siegel 2007). For instance, if a current regime is displaced by a revolution, the new regime may seek political retribution against firms with ties to previous political leaders. Because revolutions are much more volatile than traditional regime turnover, it is not clear whether connections with political stakeholders of any type benefits ventures in countries facing such uncertainty.

In addressing this issue, we propose that relationships with military stakeholders will be more beneficial for venture survival in countries experiencing revolutions, for a few reasons. First, comparative analyses of governmental revolutions showed that unlike political institutions, military institutions are more resilient and continue to function even amidst revolutions (Calvert 1970). Russell (1974, p. 12) found that "no revolution ... can triumph without the help of a portion of the armed forces." Second, military ties can provide needed security resources. Political revolutions by definition almost always arise through violent force (First 1970), which can threaten the safety of organizational personnel and operations. The 1979 Nicaraguan Revolution, for example, led to the deaths of an estimated 35,000 people (1.2\% of the population) and material damage estimated at $25 \%$ of gross national product (Austin and Ickis 1986). Similarly, during the Tunisian and Egyptian Arab Spring, Armanios and Adley (2016) found, government revolutions undermined the state's ability to maintain security and to ensure that state financial institutions were adequately working, which negatively impacted venture survival. Throughout periods of revolution, military ties can give ventures material support in the form of physical security by stationing troops near them, or by giving them information to help protect them from violence. Not only is this likely to create a spillover effect in which nearby stakeholders benefit from the increased security, but such acts may also reassure financial institutions and other stakeholders that grant resources to such ventures. 
Third, firms with military ties may likely be spared the uncertainty related to security concerns that accompanies revolutions. The military is generally the government institution least affected by revolutions, becoming by default "the only effective" institution that can preserve some degree of security and order (Pye 1961, p. 91). For this reason, when existing political regimes are violently disrupted, the country's citizenry often perceives the military as a "possible savior" (Pye 1961, p. 92) in preventing total institutional collapse, violence, and general chaos (Shils 1962). The military's command over weaponry and soldiers, for instance, may give pause to revolutionary leaders seeking to target particular firms to which military leaders have ties. This assumption is likely to be shared among the firms' stakeholders such as investors, creditors, and supply-chain actors, who may continue to extend resources to those firms. Collectively, we expect these benefits to enhance firm survival and argue:

Hypothesis 4: Organizational ties to military stakeholders will have a greater impact on enhancing venture survival in countries experiencing political revolutions.

\section{METHODS}

To assess the differential effects of venture relationships with military and political stakeholders on new venture survival, we examined all airlines founded in 10 South American countries (Argentina, Bolivia, Brazil, Chile, Colombia, Ecuador, Paraguay, Peru, Uruguay, and Venezuela) from the emergence of the industry, in 1919, when the first two Latin American airlines were founded in Argentina and Colombia, to 1984 (the last year for which our data exist). Two hundred eighty-two airlines were founded in these countries during this period, of which 147 failed, 49 were acquired, and 20 were expropriated. We examine the airline sector because it was considered one of the "national security industries," such as steel, automobiles, energy, and telecommunications, in which politicians and "the military maintained a

consistent interest" (Schneider 1991, pp. 225, 228). Thus, the airline sector is an industry where we would expect to see political and military officials have interest and experience in the industry, thereby easing affiliation with a new venture seeking advisers and investors. Our data include all airlines from these countries that ever received a license to operate. The data come from Davies' (1983) Airlines of Latin 
America since 1919, the magazine Flight International, and the Ronald E. G. Davies collection of statistics on world airlines archived at the Smithsonian National Air and Space Museum in Washington, DC. From these sources, we obtained the dates that each airline began and ceased operation, merger and acquisition activity, the number of airlines operating in a given country, and firm characteristics such as domestic or international focus, the number and size of planes in use, military and political ties, and state and foreign investment.

\section{Historical Background and Empirical Context}

As is common in underdeveloped and developing economies, militaries in Latin America have accrued tremendous power and autonomy from political officials as state leaders have invested in growing and professionalizing the armed forces (Reno 1997, Soeters 2007). After countries in Latin American gained independence, elected officials in these countries generally invested heavily in armament, labor, and training to increase the military's ability to enforce state rules, suppress uprisings, and deliver adequate security (Blomberg 1996). For example, in the nineteenth century, several newly created Latin American countries hired France and Germany, whose armies were among the most prestigious in the world, to train and modernize their militaries (Resende-Santos 2007). As a result, these new nations were able to offer high-level technical and scientific education and to produce military professionals such as engineers and certified arms experts (Nunn 1983). Such training provided military expertise, hierarchy, discipline, and a culture of solidarity (Rouquié 1987).

Military professionalization and resources led to greater unity among members of the military and autonomy from elected officials. Typically, politicians did not appoint military leaders; instead, all servicemen, including officers, were promoted by internal military committees, leading to lifetime military careers and stable hierarchical leadership (Arceneux 2001). Because military leaders in Latin America generally attended only military universities, they were indoctrinated in military values, creating an intense culture of solidarity, cohesiveness, and superiority that extended beyond retirement (Rouquié 1987). Like the corporate elite who join exclusive social clubs to increase their solidarity and power (Marquis et al. 2013), military officers established and joined clubs and associations where they could 
stay in contact with each other, discuss current events, and remain influential in national military affairs. For example, retired general Carlos Washburn Salas, in addition to being a founding board director of the Peruvian airline APSA, was a founding member of the Association of General and Admiral Officers of Peru, an officers' club with the purpose of "stimulating, strengthening and maintaining camaraderie and friendship ties among associates" (ADOGEN 2014).

The combination of weaponry, autonomy, and professional status created a cohesive institution with unmatched coercive power. Political instability, leftist governments, and civil corruption were often the pretext for the military's use of deadly force (O’Donnell 1988). According to the military, rooting out state corruption necessitated "de-politicization" through coercive means, such as the assassination and kidnapping of suspected members of political parties and individuals that threatened the military's position, including "leftists, union and peasant leaders, priests and nuns, intellectuals, students and teachers” (McSherry 1999, p. 38). Many government programs allegedly created to promote political stability and economic reforms in Latin America, such as Operation Condor and the National Reorganization Process, became institutionalized systems of state terror designed to crush opposition to military-endorsed reforms (McSherry 1999). Fatalities no longer resulted from "open combat with violent demonstrators in the streets but included an apparent effort toward the systematic elimination or at least the exclusion through terror of an entire political class and extending even to those simply suspected of harboring resentment of the regime, including members of the middle class and upper classes and even the military itself" (Farcau 1996, p. 16). Among the documented human rights violations include the abduction and disappearance of political dissidents and young children and mass executions involving firing squads and ejection from aircraft over the sea (McSherry 1999).

To maintain loyalty among the officer ranks, military chiefs allowed military personnel to engage in a variety of rent-seeking behaviors, such as the embezzlement of government funds and solicitation of bribes from military contractors (Smallman 1997, Leigh and Evans 2005). Outside the military institution, military officers, both active and retired, were generally free to pursue economic opportunities to supplement their income and pension (Brömmelhörster and Paes 2003). One such opportunity entailed 
receiving equity and payment for becoming a board member or adviser of a new business venture.

Business endeavors in "national security industries" that have both military and civilian utility, such as airlines, automobiles, energy, telecommunications, and aerospace, were particularly attractive because (a) these were areas in which military officers have experience through military contracts and (b) these were strategic sectors that supported the functions of the armed forces (Schneider 1991). If the business grew, was sold, or went public, the military officer could profit substantially. Retired colonel Marcilio Jacques Gibson, for example, was a major shareholder of Loide Aéreo Nacional, a domestic airline in Brazil. When the firm was sold to VASP (Viação Aérea São Paulo) in 1975 for 48 million (US) dollars, Colonel Jacques Gibson became a multimillionaire. He subsequently invested his share of the proceeds in another regional startup airline, TABA (Transportes Aéreos da Bacia Amazônica).

\section{Dependent Variable}

Firm Failure. To investigate how ties to political and military actors affect organizational survival, we use the date of organizational failure as our dependent variable. Only airlines that ceased operation were designated as failed. Those that were acquired were designated as exited and were dropped from the analysis.

\section{Explanatory Variables}

Political Ties. In accordance with prior work (Faccio et al. 2006), we coded a firm as having political ties if one of its large shareholders, board members, or top firm officers was a member of the legislature or the national or provincial executive; a cabinet member or agency chief; or a close relative (such as a sibling or spouse) of a top politician. Like military officers, political actors would be motivated to invest in or join a new startup for economic gain. This variable is also binary $(1=$ yes, $0=$ no $) ; 37$ ventures had political ties. ${ }^{2}$ Airlines without state investment and those engaged in international routes were more likely to have established ties with political officials. Ventures without foreign investment and those with international routes were more likely to have both state and military ties.

\footnotetext{
${ }^{2}$ All political ties were civilian. None of the political actors in this study was previously a career military officer.
} 
Military Ties. Similar to political ties, and using archival information from the Smithsonian, we identified an airline as having a military tie when a high-ranking military officer (such as a colonel, general, or admiral) or a close relative (such as a sibling or spouse) of the high-ranking officer belonged to its founding senior-management team or advisory board or was a major investor at founding. The variable is binary $(1=$ yes, $0=$ no). Fifty-seven of 282 ventures had military ties, and $37(65 \%)$ of the military officers were retired. ${ }^{3} \mathrm{We}$ concentrate on the armed forces because they are typically the most powerful and best-organized coercive state institution; they are also more heavily armed than any other state entity and enjoy a near monopoly on effective weapons (Finer 2002). ${ }^{4}$ Airlines with greater assets and state investment were more likely to have established military affiliations. However, ventures with foreign investments were less likely. Six ventures had ties to both political and military actors, and three of those eventually failed.

\section{Moderator Variables}

Declining Economic Environment. We measured declining economic environment using the average change in imports and exports over a 4-year running average. Scholarship has repeatedly affirmed that trade is a strong measure of economic wellness, and the correlation is high for developing and underdeveloped economies that rely heavily on exports (Frankel and Romer 1999, Feder 1983, Acemoglu et al. 2005). In South America, "the impetus for industrial development came from the expansion of foreign trade" (Haber 2006, p. 540), and all 10 countries during our time period relied heavily on trade for economic growth (Bulmer-Thomas et al. 2006). This variable was then reversecoded. We used a running average to capture trends in economic contraction and growth as well as to

\footnotetext{
${ }^{3}$ We found no effect of military rank on venture survival.

${ }^{4}$ In Latin America, the military has been shown to exert its influence over state leaders through blackmail, coups d'état, and occasionally military rule. When democracy was reinstated, the armed forces either participated in the policy-drafting process directly or shaped regulatory structures indirectly by retaining the right to veto regulations and programs (Fitch 1998). For example, the military's absolute veto power was codified in the constitutions of Chile, Argentina, Brazil, and Ecuador (Fitch 1998). Highlighting the importance of the military, studies indicate that countries with weaker political institutions devote a larger share of their government finances to the military in order to deal with political unrest and anarchy (Blomberg 1996).
} 
address any annual data aberrations. ${ }^{5}$ We obtained these data from the National Capabilities Dataset (Singer, Bremer and Stuckey 1972).

Political Effectiveness. We measured stakeholders' political effectiveness in a country using the highest score for whether state lawmakers have substantial authority over policy, taxation, and disbursement of government funds, as well as the power to override executive vetoes. We obtained this variable from the Cross-National Time-Series Data Archive (Banks 2008, p. 16). ${ }^{6}$

Revolutions. We captured the volatility of political institutions by summing the number of revolutions or illegal or forced changes to the top government elite or any attempt at such a change in a given year and country. These data come from the Cross-National Time-Series Data Archive (Banks 2008).

Armed Conflict. We measured armed conflict using the yearly sum of incidents of armed activity and violence that resulted in at least 500 directly related deaths over the course of a year. The data come from the Correlates of War Index (Sarkees and Wayman 2010) and the Major Episodes of Political Violence dataset (Marshall 1999).

\section{Control Variables}

We controlled for environmental and organizational factors that could affect venture survival. We included economic variables that may affect airline failure and expropriation. We controlled for country population and GDP per capita (Flores and Aguilera 2007). Because government borrowing can affect countries' credit ratings, foreign direct investment, and inflation, we controlled for the fiscal budget balance, following prior research, by subtracting government spending from revenues (Vaaler and McNamara 2004). Given that a large share of an airline's revenue flows from cargo transport, we

\footnotetext{
${ }^{5}$ We also tried averages over 3- and 5-year periods as well as the change in just imports and exports over similar periods, and the results were robust.

${ }^{6}$ The Cross-National Time-Series Archive is a database created by the late Arthur Banks, a political science professor at Binghamton University. It comprises 196 economic, demographic, and political variables covering 200 years of annual data for over 200 countries. Its data are widely used by academic, government, finance, and the media and are the foundation for many established political economy variables (Boli and Thomas 1997, Easterly and Levine 1997).
} 
controlled for that opportunity by capturing total country trade (total trade per capita). We also controlled for a country's corresponding-year trade balance, calculated by subtracting the value of goods exported from the value of goods imported, and for the ratio of defense to government expenditures. Information on government spending, population, GDP change, and trade came from the Cross-National Time-Series Data Archive (Banks 2008). All financial data are in US dollars. We also included measures of airlinesector density and age. Airline-sector density, modeled as the number of operating airlines by countryyear, controls for intra-sector competition in a given country, following prior research (Carroll and Hannan 2000, Bermiss et al. 2017). We measured airline-sector age as the number of years since a country's first airline was founded. This variable also controls for other changes that may have occurred linearly with the passage of time. We included a measure of political constraint, which takes into account government checks and balances or the degree to which any one political actor can easily enact policy changes (Henisz 2002). We also controlled for the degree to which a state was authoritarian and democratic using the polity index from the Polity IV Dataset (Eckstein and Gurr 1975, Marshall and Jaggers 2000). This variable captures the institutionalized authority patterns that characterize formal polities and ranges from -10 (authoritarian) to +10 (democratic).

We controlled for firm size, by summing the number of passenger seats in active aircraft in a given year, and firm age. Because companies with operations concentrated in one particular country face added risk (Henisz and Zelner 2010), we included a binary variable indicating whether the organization was a domestic airline (=1), meaning it only flew routes within the country's borders. The Smithsonian archives also revealed whether an airline had substantial foreign investment. ${ }^{7}$ Because exact percentages of foreign ownership were unavailable, we indicated whether an airline had substantial foreign investment, meaning that the ownership was large enough to be listed in company and regulatory reports, using a binary variable. Because airlines that have government investment may enjoy privileged regulation and

\footnotetext{
${ }^{7}$ During the period in question, none of the countries in the study were signatories to the World Bank's Convention on the Settlement of Investment Disputes, which stipulates protection of foreign property, specifies investor recourse, and acts as a deterrent against expropriation. All countries in the dataset had enacted laws prohibiting majority foreign ownership of airlines.
} 
subsidized credit (Inoue et al. 2013), we also controlled, using a binary variable, for whether an airline had any state investment. Of the 282 firms, 51 had substantial minority foreign investment and 39 had some state investment. ${ }^{8}$

We controlled for factors that could affect the likelihood of a military officer affiliation with a new startup. We included a measure of military size using the total sum of personnel, as a larger military could increase the value of military affiliations to a firm. We also included the percentage of workers in industrial production to gauge the country's industrial activity. Greater industrial activity may give military officers more-attractive alternatives than affiliating with a brand-new startup. These data come from the Cross-National Time-Series Data Archive (Banks 2008).

\section{Analysis}

To test the impact of political and military ties on organizational failure, we used a Gompertz eventhistory analysis and a two-stage probit analysis. The Gompertz analysis has the general hazard form $h(t)=\exp (\beta x) \exp (p t)$, where $x$ is a vector of covariates, $\beta$ is a vector of regression coefficients, and $p$ is an ancillary parameter to be estimated from the data. We conducted exploratory analyses to determine which hazard rate would be appropriate, including visually examining the pattern of duration dependence and applying the Akaike Information Criterion and Schwarz's Bayesian Information Criterion tests to differentiate between nested models. These exploratory analyses indicated that the Gompertz model was the best fit for our data. We used maximum likelihood estimation and the Huber-White sandwich estimator of variance, which adjusts standard errors to account for multiple observations per year.

We implemented a two-stage probit regression as a robustness test of the impact of military and political ties on firm failure. We also use this supplemental analysis to address possible selection issues related to military affiliations at venture startup; this is described in more detail in our "Robustness Tests" section. We tested for multicollinearity and found that all variance-inflation factors in the event-history

\footnotetext{
${ }^{8}$ One airline was owned by the military; we classified it as state-owned.
} 
analysis were less than 3.86 and that the majority were less than 1.99 , indicating an acceptable level of multicollinearity (Afifi et al. 2004).

\section{RESULTS}

The descriptive statistics and bivariate correlations appear in Table 1, and the event-history analysis predicting organizational failure appears in Table 2. The two-stage probit analysis is reported in Tables A1 and A2. Consistent with prior literature, the coefficients shown in Model 2 of Table 2 indicate that having military and political ties respectively decreases the probability of venture failure by $79 \%$ and 44\%. ${ }^{9}$ Log-likelihood tests indicated that the coefficients of military ties and political ties were statistically distinct from each other. In addition, some of the control variables in Table 2 had a significant impact on venture failure: older firms, greater sector density, country GDP per capita, and political constraints were associated with increased airline failure; larger firm size, greater surplus fiscal budgets, higher political effectiveness, and greater ratio of defense to government expenditures were associated with increased survival. ${ }^{10}$

\section{$* * * * *$ Insert Table 1 and Table 2 about here $* * * * *$}

Turning to the tests of our hypotheses, in Hypothesis 1, we argued that ties to political stakeholders would be more beneficial for venture survival in countries with a declining economic environment. Model 3 offers support for Hypothesis 1 and shows that the benefit of political ties was enhanced as the economic environment declined. As reported in Model 3, ventures with political ties were about 92\% less likely to fail when a country's trade declined by more than one standard deviation, whereas ventures in

\footnotetext{
${ }^{9}$ In analyses not reported here, we found that influence of political ties on firm failure varied according to their position in government (see Zhu and Chung 2014). For example, federal-level ties reduced failure more than stateand provincial-level ties. However, military ties still had a greater impact on ventures than the most influential state ties. We also found that ties to active military officers had a greater impact on venture survival than retired military officers.

${ }^{10}$ In analyses available in the Appendix, we also interacted our two-way interactions with firm density to capture competition and with domestic airlines to capture geographic concentration of operations. We found that political ties are more beneficial for venture survival when competition is high and where political officials have greater power to compose policy whereas military ties are more beneficial for domestic airlines located in countries experiencing armed conflict and government revolutions.
} 
similar contexts with military ties received no significant benefit. In Hypothesis 2, we argued that political ties would be more beneficial for venture survival in countries where political officials enjoy high political effectiveness. As Model 4 indicates, this hypothesis was supported. Ventures with political ties were about $76 \%$ less likely to fail where political effectiveness was high, whereas firms in similar contexts with military ties received no significant benefit. For instance, in our study, one of the directors of the Colombian airline LAC, who had ties to the nation's president, was able to help the airline obtain an operating permit within days without any issues (see Figures $1 \& 2$ ).

Our models also offer support for Hypothesis 3, which posited that ties to military stakeholders would have a greater beneficial impact on new ventures in environments with armed conflict. The coefficients in Model 5 show that in countries with a one-standard-deviation increase in the amount of armed conflict, ventures with military ties were not likely to fail; the probability of failure is an astonishingly low $5.6 \times 10^{-13}$. In contrast, having political ties was marginally more detrimental to venture survival in similar contexts, suggesting that firms with known political ties may be targeted by terrorists or armed insurgencies seeking to "attain a political goal or communicate a political message" (Czinkota et al. 2004, p. 45).

In Hypothesis 4, we argued that military ties would be more beneficial for venture survival during periods of government revolution. The results from Model 6 support our argument: in countries with a one-standard-deviation increase in the number of revolutions, firms with military ties were $99.94 \%$ less likely to fail, whereas firms with political ties in similar contexts received no significant benefit. These results are consistent with anecdotal evidence of the value of military ties in protecting businesses throughout Latin America (Shemo 1996). For example, one executive described how the prevalence of violence and crime made military protection essential to his firm's launch in Colombia. He remarked, "We went in with the support of the armed forces.... Without [the military's] support, we would not have been able to come in" (Forero 2004). The military officer in charge of the battalion guarding this same firm acknowledged the security resources they provide: “There's a feeling of safety, that we're keeping the peace. We've provided confidence so companies can explore here" (ibid) (see Figures $3 \& 4$ ). 


\section{Robustness Tests}

We conducted additional robustness tests to address (a) selection effects and related potential endogeneity, (b) data limitations, (c) model robustness, and (d) exogenous shocks and tie mechanisms.

Selection Effects and Unobserved Heterogeneity. One could argue that military officers join only the highest-quality ventures, in which case military ties would be a proxy for unobserved quality. We find this argument implausible for several reasons. First, the limited historical data on tie establishment suggest that airline founders reach out to military officers, not the reverse. Second, we have no evidence that military officers are more adept than others at judging a new venture at founding. The literature on political connections to new ventures offers no evidence that government officials such as policymakers and state executives accurately judge a new venture's potential (Li and Zhang 2007). Similarly, we would expect that the ability of military officers to judge a new venture's prospects is not likely to be greater than that of other governmental officials. Finally, the historical failure rate for new airlines with ties to the military is an astonishingly low $15 \%$, much lower than the failure rate for new ventures supported by the very best venture capital firms, which are composed of professional full-time investors. It is unlikely that this is because military officers are far better at assessing the quality of a new venture than professional investors are.

Another question arises: What causes military officers to affiliate with a startup rather than with a less risky business endeavor? To address this, we conducted a supplemental two-stage probit analysis of the likelihood of military-tie affiliation when an establishment is founded and the impact of the military tie on whether the venture fails (see Appendix Tables A1 and A2). In choosing instruments, we used variables that were correlated with ventures having a military tie but not correlated with organizational survival. These factors — size of the military and percentage of workers in industrial production—were described in the "Control Variables" section. The results in Table A1 suggest that military officers were more likely to affiliate with new ventures when there were fewer alternative business opportunities due to low industrial output and when larger military size increased their coercive power. The results in Table A2 offer robust support for our arguments that military ties improve venture survival. 
Data Shortcomings. We have annual data on military and political ties for $80 \%$ of the firms. For the remaining $20 \%$, we cannot accurately measure from the data when a military tie ends. To address this issue, we ran an analysis with only the $80 \%$ of firms for which we have annual tie data. The results did not change. Additionally, of the firms for which we do have annual data, in only three instances did the military officer leave the business or sell his holdings before an event (e.g., failure, expropriation, acquisition, or exit) occurred, suggesting that the ties are particularly durable. We also ran survival analyses with military ties ending after 10,5, and 3 years, and we lagged the military-tie variable by 2 years. In all these analyses, we found the results to be significant for the failure. We also compared small and large airlines to tease out any differences in advisory-board changes. Research suggests that smaller firms are less likely to experience advisory-board turnover than large firms and thus would be likely to maintain military ties longer (Harrison et al. 1988). We conducted failure analyses comparing the two groups and found the organizational effects of military ties to be significant for both.

Model Robustness. We conducted a competing risk analysis that takes into account the risk of three types of exit (failure, expropriation, and acquisition) using the same variables, and we found that the predicted interaction effects of political and military ties on venture survival still hold (Fine and Gray 1999). ${ }^{11}$ Because the competing risks analysis increases the number of organizational events in a particular model, it is highly robust for measuring the effects of military and political ties on organizational failure and ruling out alternative outcomes associated with firm exit.

Exogenous Shocks (Natural Disasters). We also employed some external shocks to tease out the underlying mechanisms of political and military ties. Specifically, we obtained all recorded natural disasters (e.g., earthquakes, floods, epidemics) from the EM-DAT International Disaster Database, which has been used in prior management studies (Oh and Oetzel 2011). According to the database, a disaster is

\footnotetext{
${ }^{11}$ The competing risks regression differs from conventional risk models in that it uses the cumulative incidence function (CIF) to consider not only the subhazard for the event of interest type $1, \mathrm{~h}_{1}(\mathrm{t})$, but also the subhazards of concurrent competing events, $\mathrm{h}_{2}(\mathrm{t}), \mathrm{h}_{3}(\mathrm{t})$, and $\mathrm{h}_{\mathrm{i}}(\mathrm{t})$. Thus, a competing risks regression treats the CIF as a function of all hazards, which in the case of these data are failure, expropriation, and acquisition (for example, $h_{1}(t), h_{2}(t), h_{3}(t)$, $h_{i}(t)$, whereas conventional measures of prevalence $(1-K M)$ treat the CIF as a function solely of $h_{1}(t)$.
} 
"a situation or event which overwhelms local capacity, necessitating a request to national or international level for external assistance" (EM-DAT 2016, p. 2). Governments tend to respond to large-scale disasters by expending funds to aid and support individuals and businesses and by mobilizing armed forces personnel and equipment to administer security and to assist in relief efforts (Schneider 1992). For instance, after the 8.8-magnitude earthquake in Chile, looters pillaged and torched stores, and the physical safety risks were so great that one organizational leader stated, "In some areas, we don't go anywhere without police or military protection" (Prada and Moffett 2010). Ventures with military and political ties may benefit from these actions. In results not reported here, we find that large-scale natural disasters (where more than 1,000 people die) increase the value of both military and political ties for venture survival and that this effect varies temporally depending on the type of tie. In the year in which a disaster occurs, military and political ties both significantly augment survival. In the next year, however, only ventures with political ties receive additional benefits. We believe these results support our arguments of distinct resources that the ties offer. In the year of the disaster, ventures with military ties benefit from the government's mobilization of troops to provide security amid the chaos that generally follows large-scale disasters, such as looting, vandalism, and violent crimes, whereas ventures with political ties benefit from increased government expenditures. However, after order has resumed and troops pull out, only those firms with political ties continue to benefit from multi-year government aid and rebuilding efforts.

\section{DISCUSSION}

Organizations engage in various nonmarket strategies to create a favorable environment, including managing relationships with nonmarket stakeholders who can buffer them from environmental uncertainty (Freeman 2010, Navis and Glynn 2011, Hiatt and Park 2013, McDonnell and King 2013, Haveman et al. 2017). We build on this growing literature by examining how organizations manage relationships with heterogeneous stakeholders that provide distinctive resources essential to addressing different environmental conditions. Using a unique dataset on all new ventures established in the airline industry in 10 Latin American countries over a 65-year period, we examined new venture relationships with two different types of government stakeholders: military and political leaders. We found that venture 
ties to military and political stakeholders increase venture survival and that these effects are amplified when environmental conditions necessitate the use of the types of resources provided by each actor. Specifically, the results indicate that relationships with political actors increasingly enhance survival in countries experiencing declining economic conditions and where political stakeholders have a greater ability to enact policy. Relationships with military leaders, by contrast, appear to become more influential in enhancing venture survival by providing security benefits under conditions of armed conflict and revolutions. The results also showed that political ties were detrimental to new venture survival in contexts of armed conflict, thereby speaking to research that highlights the complex nature of businessgovernment relationships (Siegel 2007).

This research makes several theoretical contributions to nonmarket strategy and stakeholder management theories. First, this study responds directly to recent calls for research to explain how organizations can effectively leverage relationships with heterogeneous stakeholders to enhance their performance (Henisz et al. 2014, Dorobantu and Odziemkowska 2017). Although scholars have begun to examine the potential impact of heterogeneous stakeholders on organizational strategy and performance (Zhu and Chung 2014, Hiatt et al. 2015, Tantalo and Priem 2016), the theoretical development of how firms can effectively manage their relationships with various stakeholders is still in its early stages. We extend existing scholarship by conceptualizing the distinct resources provided by two different stakeholders and delineating the institutional conditions under which those relationships are most likely to enhance new venture survival (Webb et al. 2009; Eberhart et al. 2017). In doing so, we invite scholars to consider the distinct benefits and liabilities that heterogeneous stakeholders can offer firms in future stakeholder management studies such as investigating the dynamics between firms and multiple stakeholders including the reciprocal nature of how these actors influence each other (Lee, Struben, and Bingham 2017, Durand and Georgallis 2017). For instance, future studies could consider how different stakeholders not only influence individual organizations, but also how the interaction between these stakeholders and firms shape broader market dynamics and evolution, including influencing the underlying values, meanings, practices, and technologies that constitute market categories. Moreover, 
although our findings suggest that cultivating a portfolio of relationships with different types of stakeholders may be an effective strategy, one limitation of this study is that we were unable to observe the process by which firms manage the costs and benefits associated with creating and maintaining such relationships. This creates an opportunity for future research to examine potential factors and related trade-offs that organizations must consider in determining the optimal number and mix of stakeholder relationships that they should maintain.

We also further research on government stakeholders by taking a pluralistic view of government and distinguishing between political and military leaders and the different resources they control. Although some studies have investigated the relationships between organizations and various government actors, these relationships have been generally conceptualized as substitutes that allocate similar resources. This limitation may be due to prior literature taking a monolithic view of the state and emphasizing policymakers and the policy and economic resources they can offer firms (McDonnell and Werner 2016). However, most democratic governments are composed of actors that create policy, such as lawmakers, and actors that enforce it, such as agency bureaucrats, the police, and military (Baron et al. 1986, Kalev et al. 2008). Our findings broaden stakeholder management theory by examining an overlooked yet powerful government stakeholder in underdeveloped and developing economies — the military — and elucidating how building relationships with military leaders can give organizations access to resources that help to mitigate challenges associated with violence and conflict. More generally, this analysis highlights the need for future stakeholder research to take a pluralistic view of the government when seeking to understand the impact of government stakeholders on firms, the strategies by which firms may manage government relationships, and the ways that community stakeholders may engage with various government stakeholders to exert pressure on firms.

By taking a pluralistic view of government, this study also speaks to dependency theory research, which has been used by political scientists to explain economic investment and firm entry and performance in developing economies. This theory describes the close relationship between agency officials and the private sector in which state bureaucrats seek information from local business elites and 
multinational corporations to enhance their rulemaking capabilities and effectiveness, and elites and multinationals seek policy favors from state officials to protect their property rights and rents (Evans 1979, Schneider 1991). More recently, strategy scholars examining business-government relations in Latin American have arrived at conclusions that are consistent with the arguments of dependency theorists, finding that relations with government agencies officials play a pivotal role in organizational performance (Inoue et al. 2013, Musacchio and Lazzarini 2014, Bucheli and Salvaj 2013). By highlighting the importance of examining the heterogeneous effects of government stakeholders on organizational outcomes, this study emphasizes the value of bringing dependency theory into future stakeholder management research and, in particular, of examining how relationships to political leaders and bureaucratic-agency officials may provide distinct and potentially complementary resources that may differentially benefit organizations.

Although this study focuses exclusively on firms operating in emerging economies of Latin America, we believe this framework is applicable to other countries where state capacity is limited, armed conflict and political volatility are high, and the military is relatively well organized and powerful, such as developing and underdeveloped economies in Africa and Southeast Asia (Hoskisson et al. 2000, Ault and Spicer 2014, Guillen and Capron 2016). For example, Ornyx Diamonds is a mining company based in the Democratic Republic of Congo and has, among its equity holders, high-ranking Zimbabwean military officers. Notwithstanding the extensive lawlessness, looting, violence, and extortion that have caused most businesses in Congo to fail, Ornyx's operations have been spared due to the stationing of Zimbabwean soldiers at their facilities (Paes and Shaw 2003). Other studies suggest that during riots in Indonesia, businesses with ties to high-ranking military officers were spared due to the strategic placement of soldiers to protect them (McCulloch 2003).

Future research might explore further how entrepreneurs in underdeveloped and developing economies can protect themselves by affiliating with military officers. For instance, does the value of these complementary resources vary depending on the relationship between political and military officers 
and the alignment or misalignment of their interests? To what extent can firms transform the public goods of physical security into private goods through their ties with coercive military actors? (Gambetta 1996). Additionally, what are the ethical implications of ties to coercive stakeholders, and what are the costs of such ties to the venture? (Frooman 1999). Resource dependency theory suggests that organizations can become "controlled by an external source to the extent they depend on that source for large proportion of input or output" and, as such, end up surrendering "some of [their] own autonomy" (Pfeffer and Salancik 2003, p. 271). Can military stakeholders compel ventures to give up autonomy and comply with immoral action? For example, during Argentina's dirty war in the 1970s, did airlines with military ties conspire with military leaders to persecute and abduct political dissidents?

Relatedly, do affiliations with high-ranking military officers foster greater corporate malfeasance by reducing the risk of legal investigations (Stuart and Wang 2016)? For example, in 1981, an Argentine aircraft operated by Transporte Aéreo Rioplatense (TAR) was forced down by a Soviet Air Force fighter for allegedly invading Soviet Union airspace; all on board died. News articles alleged that the plane carried military equipment to Iran, and international leaders threatened to sanction TAR and Argentina for violating the arms embargo against that nation. Argentine Brigadier General Rodolfo Etchegoyen, one of the airline's directors, volunteered to investigate the crash scene, determine the cause of the crash, and address the allegations of illegal arms trading. According to General Etchegoyen's official report, the damage to the plane was so great that the black box did not survive, the plane could not be identified except for one piece of metal on which was painted the Argentine flag, and there was no evidence that the plane carried illegal goods to Iran. The report effectively ended the investigations and the threat of international sanctions. ${ }^{12}$ As this anecdote indicates, understanding the ethical implications of such relationships is of utmost importance.

Finally, in many emerging and underdeveloped countries, such as China, Egypt, Turkey, Zimbabwe, Indonesia, Brazil, and Pakistan, the military is affiliated with large industrial complexes (Brömmelhörster

\footnotetext{
${ }^{12}$ It was revealed later that TAR was hired by Israeli and American spies to transport 360 tons of U.S.-made tank spare parts and ammunition from Tel Aviv via Cyprus to Tehran.
} 
and Paes 2003). A recent illustration of this is military-run businesses in the Russian Federation. After the fall of the Soviet Union, financial support for the military was slashed, and the government authorized active military members' participation in business activities to generate revenue for the institution and to allow officers to supplement their incomes. As a result, the heads of military forces expanded their divisions into a variety of business fields, such as commercial space launches, hospitals, sales of military weapons, and automobile and railroad manufacturing. Some army officers even branched out into activities far removed from defense, such as agribusiness. In 2000, over 14,000 soldiers and 500 military trucks were used to harvest and process crops (Gonchar 2003). Honduras offers another illustration. In the early 2000s, the armed forces' pension fund (Instituto de Previsión Militar) was ranked the fifth-largest economic entity, alongside multinational banana operations, with investments in banking, cement, communications, and military armament. Unlike American and European pension funds, the Honduran military pension fund is an active investor, taking controlling ownership in most instances and placing high-ranking military officers on the firms' boards of directors (Castro and Zamora 2003).

Despite the prevalence of military-run businesses in underdeveloped and developing economies, we know little about them. How efficient are these businesses, and what challenges and benefits do they present to local ventures and multinational companies? What role do they play in fostering or hindering entrepreneurship and foreign direct investment? In Nicaragua and Honduras, for instance, entrepreneurs have "frequently leveled accusations of unfair competition" against military businesses (Castro and Zamora 2003, p. 46).

Important research topics also include exploring how venture connections to prominent stakeholders other than political and military leaders may affect organizational performance (Kraatz 1998). For example, religions and churches have wielded tremendous influence not only over their followers but also over national policy (Tracey 2012). In what way would relationships with the Assembly of Experts in Iran or with the Brahmans in India affect firm outcomes in those countries? In another example, research on social movements and organizations suggests that formal and informal social movements such as bloggers have been extremely effective at mobilizing street protests that threaten governmental and corporate 
actors (Soule et al. 2014, Luo et al. 2016). For instance, during the Arab Spring of 2011, multiple protests

against governmental corruption in Tunisia and Egypt brought down governments and paralyzed military

actors. How would ties to leaders of these social movements affect venture performance? Answers to

these questions will help us better understand how firms can manage heterogeneous stakeholder

relationships to enhance their performance.

\section{REFERENCES}

Acemoglu D, Johnson S, Robinson J (2005) The rise of Europe: Atlantic trade, institutional change, and economic growth. Amer. Econ. Rev. 95:546-579.

ADOGEN (2014) Asociacion de oficiales generales y almirantes del Peru; Quienes Somos; http://www.adogen.org.pe/quienessomos.php; accessed March 31, 2014.

Afifi A, Clark V, May S (2004) Computer-Aided Multivariate Analysis (Chapman and Hall/CRC, Boca Ratón, FL).

Aldrich H, Ruef M (2006) Organizations Evolving (Sage, Thousand Oaks, CA).

Ambrus S (2002) Risky business Washington sends troops to protect an oil pipeline. Amazon Watch. Retrieved December 1, 2016 from http://amazonwatch.org/news/2002/1118-risky-business.

Arceneux C (2001) Bounded Missions: Military Regimes and Democratization in the Southern Cone and Brazil (Pennsylvania State University Press, University Park, PA).

Armanios D, Adley A (2016) How revolutions shape (or rather blur) markets: Initial insights from the Arab Spring (Working Paper, Carnegie Mellon University, Pittsburgh, PA).

Armanios D, Eesley C, Li J, Eisenhardt K (2017) How entrepreneurs leverage institutional intermediaries in emerging economies to acquire public resources. Strat. Mgmt. J. 38:1373-1390

Ault J, Spicer A (2014) The institutional context of poverty: State fragility as a predictor of cross-national variation in commercial microfinance lending. Strategic Management J. 35:1818-1838.

Austin J, Ickis J (1986) Managing after the revolutionaries have won. Harvard Bus. Rev. 64(3):103-109.

Banks A (2008) Cross-national time-series data archive (CNTS) 1815-2007. Databanks International. http://www.databanksinternational.com. Accessed July 2012.

Baron J, Dobbin F, Jennings P (1986) War and peace: The evolution of modern personnel administration in US industry. Amer. J. of Soc. 92:350-383.

BBC News (2016) Turkey coup attempt: Nearly 82,000 sacked or suspended. BBC, London.

Bermiss Y, Hallen B, McDonald R, Pahnke E. (2017) Entrepreneurial beacons: The Yale endowment, run-ups, and the growth of venture capital. Strategic Management J. 38: 545-565.

Blomberg S (1996) Growth political instability and the defence burden. Economica 63:649-672.

Boli J, Thomas GM (1997) World culture in the world polity: A century of international nongovernmental organization. Amer. Soc. Rev. 2:171-190.

Brömmelhörster J, Paes W, eds. (2003) The Military as an Economic Actor: Soldiers in Business (Palgrave Macmillan, New York).

Bucheli M (2008) Multinational corporations, totalitarian regimes and economic nationalism: United Fruit Company in Central America 1899-1975. Bus. Hist. 50(4):433-454.

Bucheli M, Aguilera R (2010) Political survival energy policies and multinational corporations. Management Int. Rev. 50(3):347-378.

Bucheli M, Kim M (2015) Attacked from both sides: A dynamic model of multinational corporations' strategies for protection of their property rights. Global Strategy J. 5(1):1-26.

Bucheli M, Salvaj E (2013) Reputation and political legitimacy: ITT in Chile 1927-1972. Bus. Hist. Rev. 87(04):729-756. 
Bulmer-Thomas V, Coatsworth J, Cortes-Conde R (2006) The Cambridge Economic History of Latin America: Volume 2, The Long Twentieth Century (Cambridge University Press, Cambridge, UK).

Carlos W, Lewis B (2017) Strategic silence: Withholding certification status as a hypocrisy avoidance tactic. Admin. Sci. Quart. forthcoming.

Carroll G, Delacroix J, Goodstein J (1988) The political environments of organizations: An ecological view. Res. Organ. Behav. 10:359-392.

Carroll G, Hannan M (2000) The Demography of Corporations and Industries (Princeton University Press, Princeton, NJ).

Castillo E, Stevenson M (2014) Mexico legalizes vigilantes, nabs cartel leader. Associated Press, January 27.

Castro A, Zamora K (2003) Soldiers as businessmen: The economic activities of Central America's militaries. Brömmelhörster J, Paes W-C, eds. The military As an Economic Actor: Soldiers in Business (Palgrave Macmillan, New York), 32-51.

Calvert P (1970) A Study of Revolution (Clarendon Press, Oxford, UK).

Czinkota M, Knight G, Liesch P (2004) Terrorism and international business: Conceptual foundations. Suder GG, ed. Terrorism and the International Business Environment: The Security-Business Nexus (Edward Elgar, Northampton, MA), 43-57.

Davies REG (1983) Airlines of Latin America since 1919 (Smithsonian Institution Press, Washington, DC).

Dai L, Eden L, Beamish P (2013) Place, space, and geographical exposure: Foreign subsidiary survival in conflict zones. J. Int. Bus. Stud. 44:554-578.

Dai L, Eden L, Beamish P (2017) Caught in the crossfire: Dimensions of vulnerability and foreign multinationals' exit from war-afflicted countries. Strategic Management J. forthcoming.

Doh J, Lawton T, Rajwani T (2012) Advancing nonmarket strategy research: Institutional perspectives in a changing world. Acad. Management Perspectives 26(3):22-39.

Dorobantu S, Henisz W, Nartey L (2017) Not all sparks light a fire: Stakeholder and shareholder reactions to critical events in contested markets. Admin. Sci. Quart. 62(3):561-597.

Dorobantu S, Kaul A, Zelner B (2017) Nonmarket strategy research through the lens of new institutional economics: An integrative review and future directions. Strategic Management J. 38:114-140.

Dorobantu S, Odziemkowska K (2017) Valuing stakeholder governance: Property rights, stakeholder mobilization, and firm value. Strategic Management $J$. forthcoming.

Durand R, Georgallis P. (2017) Differential firm commitment to industries supported by social movement organizations. Organ. Sci. forthcoming.

Easterly W, Levine R (1997) Africa's growth tragedy: Policies and ethnic divisions. Quart. J. Econ. 112(4):1203-1250.

Eberhart R, Eesley C, Eisenhardt K. (2017) Failure is an option: Institutional change, entrepreneurial risk, and new firm growth. Organ. Sci. 28: 93-112.

Eckstein H, Gurr T (1975) Patterns of Authority: A Structural Basis for Political Inquiry (John Wiley \& Sons, New York).

EM-DAT (2016) Glossary (Centre for Research on the Epidemiology of Diseases, Catholic University of Louvain, Brussels, Belgium).

Evans P (1979) Dependent Development: The Alliance of Multinational State and Local Capital in Brazil (Princeton University Press).

Faccio M, Masulis R, McConnell J (2006) Political connections and corporate bailouts. J. Finance 61:2597-2635.

Farcau B (1996) The Transition to Democracy in Latin America: The Role of the Military (Praeger, Westport, CT).

Feder G (1983) On exports and economic growth. J. Dev. Econ. 12(1-2):59-73.

Filatotchev I, Buck T, Zhukov V (2000) Downsizing in privatized firms in Russia, Ukraine, and Belarus. Acad. Management J. 43:286-304.

Fine J, Gray R (1999) A proportional hazards model for the subdistribution of a competing risk. J. Amer. Stat. Assoc. 94(446):496-509.

Finer S (2002) The Man on Horseback: The Role of the Military in Politics (Transaction, New Brunswick, NJ). 
First R (1970) The Barrel of a Gun: Political Power in Africa and the Coup d'état (Allen Lane, London).

Fitch J (1998) The Armed Forces and Democracy in Latin America (Johns Hopkins University Press, Baltimore, MD).

Flores R, Aguilera R (2007) Globalization and location choice: An analysis of US multinational firms in 1980 and 2000. J. Int. Bus. Stud. 38:1187-1210.

Forero J (2004) Safeguarding Colombia's oil. New York Times, October 22.

Frankel J, Romer D (1999) Does trade cause growth? Amer. Econ. Rev. 89(3):379-399.

Freeman RE (2010) Strategic Management: A Stakeholder Approach (Cambridge, UK, Cambridge University Press).

Frooman J (1999) Stakeholder influence strategies. Acad. Management Rev. 24(2):191-205.

Gambetta D (1996) The Sicilian Mafia: The Business of Private Protection (Harvard University Press, Cambridge, MA).

Gargiulo M (1993) Two-step leverage: Managing constraint in organizational politics. Admin. Sci. Quart. 38(1):1-19.

Georgallis P, Dowell G, Durand R. 2017. Shine on me: Policy support for the emergent solar photovoltaic industry in Europe. University of Surrey, Working paper.

Gonchar K (2003) The largest European army in business: The case of Russia. Brömmelhörster J, Paes W-C, eds. The Military as an Economic Actor: Soldiers in Business (Palgrave-Macmillan, New York), 170-186.

Guillen M, Capron L (2016) State capacity, minority shareholder protections, and stock market development. Admin. Sci. Quart. 61(1):125-160.

Gulati R, Nohria N, Zaheer A. (2000) Strategic networks. Strategic Management J. 21(3):203-215.

Haber S (2006) The political economy of industrialization. Bulmer-Thomas V, Coatsworth J, CortesConde R, eds. The Cambridge Economic History of Latin America (Cambridge University Press, Cambridge, UK), 537-584.

Harrison J, Torres D, Kukalis S (1988) The changing of the guard: Turnover and structural change in the top-management positions. Admin. Sci. Quart. 33:211-232.

Haveman H, Jia N, Shi J, Wang Y. (2017) the dynamics of political embeddedness in China. Admin. Sci. Quart. 62(1):67-104.

Henisz W (2002) The institutional environment for infrastructure investment. Indust. Corp. Change 11:355-389.

Henisz W, Dorobantu S, Nartey L (2014) Spinning gold: The financial returns to stakeholder engagement. Strategic Management J. 35(12):1727-1748.

Henisz W, Zelner B (2010) The hidden risks of emerging markets. Harvard Bus. Rev. 88:88-95.

Hiatt S, Grandy J, Lee B (2015) Organizational responses to public and private politics: An analysis of climate change activists and U.S. oil and gas firms. Organ. Sci. 26(6):1769-1786.

Hiatt S, Park S (2013) Lords of the harvest: Third-party influence and regulatory approval of genetically modified organisms. Acad. Management J. 56:923-944.

Hiatt S, Sine W (2014) Clear and present danger: Planning and new venture survival amid political and civil violence. Strategic Management J. 35:773-785.

Hiatt S, Sine W, Tolbert P (2009) From Pabst to Pepsi: The deinstitutionalization of social practices and the creation of entrepreneurial opportunities. Admin. Sci. Quart. 54:635-667.

Hillman A, Withers M, Collins B (2009) Resource dependence theory: A review. J. Management 35:1404-1427.

Hillman A, Zardkoohi A, Bierman L (1999) Corporate political strategies and firm performance: Indications of firm-specific benefits from personal service in the US government. Strategic Management J. 20:67-81.

Hoffman A, Ocasio W (2001) Not all events are attended equally: Toward a middle-range theory of industry attention to external events. Organ. Sci. 12:414-434.

Hoskisson R, Eden L, Lau C, Wright M (2000) Strategy in emerging economies. Acad. Management J. 43:249-267.

Ingram P, Yue Q, Rao H (2010) Trouble in store: Probes, protests, and store openings by Wal-Mart, 1998-2007. Amer. J. Sociology 116:53-92. 
Inoue C, Lazzarini S, Musacchio A (2013) Leviathan as a minority shareholder: Firm-level implications of state equity purchases. Acad. Management J. 56(6):1775-1801.

Kalev A, Shenhav Y, De Vries D (2008) The state, the labor process, and the diffusion of managerial models. Admin. Sci. Quart. 53(1): 1-28.

King B, Soule S (2007) Social movements as extra-institutional entrepreneurs: The effect of protests on stock price returns. Admin. Sci. Quart. 52(3):413-442.

Kraatz M. (1998) Learning by association? Interorganizational networks and adaptation to environmental change. Academy of Management Journal 41(6):621-643.

Lee B, Hiatt S, Lounsbury M (2017) Market mediators and the tradeoffs of legitimacy seeking behaviors in a nascent category. Organ. Sci. 28:447-470.

Lee B, Struben J, Bingham C. (2017) Collective action and market formation: An integrative framework. Strategic Management $J$. forthcoming.

Leigh D, Evans R (2005) Revealed: BAE’s secret £1M to Pinochet. The Guardian, September 15.

Leuz C, Oberholzer-Gee F (2006) Political relationships, global financing, and corporate transparency: Evidence from Indonesia. J. Financial Econ. 81:411-439.

Levin D, Peker E (2016) Erdogan announces three-month state of emergency. Wall Street Journal, July 20.

Li H, Meng L, Wang Q, Zhou L (2008) Political connections, financing and firm performance: Evidence from Chinese private firms. J. Dev. Econ. 87(2):283-299.

Li H, Zhang Y (2007) The role of managers' political networking and functional experience in new venture performance: Evidence from China's transition economy. Strategic Management J. 28:791804.

Lipset S (1959) Some social requisites of democracy: Economic development and political legitimacy. Amer. Political Sci. Rev. 53:69-105.

Luo X, Wang D, Zhang J. (2017) Whose call to answer: Institutional complexity and firms' CSR reporting. Acad. Management J. 60(1):321-344.

Luo X, Zhang J, Marquis C (2016) Mobilization in the Internet Age: Internet Activism and Corporate Response. Acad. Management J. 59(6):2045-2068.

Lyon T, Maxwell J (2011) Greenwash: Corporate environmental disclosure under threat of audit. $J$. of Economics \& Management Strategy 20(1):3-41.

Mair J, Battilana J, Cardenas 2012. Organizing for society: A typology of social entrepreneuring models. J. of Bus. Ethics 111:353-373.

Marshall M, Jaggers K (2000) Polity IV Project: Political Regime Characteristics and Transitions 1800 1999 (Integrated Network for Societal Conflict Research [INSCR]. Center for International Development and Conflict Management [CIDCM], University of Maryland).

Marquis C, Davis G, Glynn M (2013) Golfing alone? Corporations, elites, and nonprofit growth in 100 American communities. Organ. Sci. 24(1):39-57.

Marquis C, Qian C (2013) Corporate social responsibility reporting in China: Symbol or substance? Organ. Sci. 25(1):127-148.

Marquis C, Raynard M (2015) Institutional strategies in emerging markets. Acad. Management Annals 9: 291-335

Marshall M (1999) Third World War (Rowman and Littlefield, Lanham, MD).

Maurer N (2013) The Empire Trap: The Rise and Fall of US Intervention to Protect American Property Overseas, 1893-2013 (Princeton University Press, Princeton, NJ).

McCulloch L (2003) Trifungsi: The role of the Indonesian military in business. Brömmelhörster J, Paes W-C, eds., The Military As an Economic Actor: Soldiers in Business (Palgrave Macmillan, New York), 94-123.

McDonnell M, King B (2013) Keeping up appearances: Reputational threat and impression management after social movement boycotts. Admin. Sci. Quart. 58(3):387-419.

McDonnell M, Werner T (2016) Blacklisted businesses social activists' challenges and the disruption of corporate political activity. Admin. Sci. Quart. 61:584-620.

Mellahi K, Frynas J, Sun P, Siegel D (2016) A review of the nonmarket strategy literature: Towards a multi-theoretical integration. J. Management 42:143-173.

McSherry J (1999) Operation Condor: clandestine inter-American system. Soc. Justice 26(4):144-174. 
Miller K (1992) A framework for integrated risk management in international business. J. Int. Bus. Stud. 23(2):311-331.

Mizruchi M (1992) The Structure of Corporate Political Action (Harvard University Press, Cambridge, MA).

Musacchio A, Lazzarini S (2014) Reinventing State Capitalism (Harvard University Press, Cambridge, MA).

Musacchio A, Lazzarini S, Aguilera R (2015) New varieties of state capitalism: Strategic and governance implications. Acad. Management Perspectives 29:115-131.

Navis C, Glynn M (2011) Legitimate distinctiveness and the entrepreneurial identity: Influence on investor judgments of new venture plausibility. Acad. Management R. 36(3):479-499.

Nehamas N, Brufatto de Oliveira J (2013) What the U.S. can learn from Brazil's epidemic of gun violence. Latitude News, September 4. Accessed June 9, 2014, from:

$\mathrm{http} / / / \mathrm{www}$.insightcrime.org/news-analysis/does-strict-gun-legislation-reduce-violent-crime-in-latam

Nunn F (1983) Yesterday's Soldiers (University of Nebraska Press, Lincoln, NE).

O’Donnell G (1988) Bureaucratic Authoritarianism: Argentina 1966-1973 in Comparative Perspective (University of California Press, Berkeley, CA).

Oetzel J, Getz K (2012) Why and how might firms respond strategically to violent conflict? J. Int. Bus. Stud. 43(2):166-186.

Oh C, Oetzel J (2011) Multinationals' response to major disasters: How does subsidiary investment vary in response to the type of disaster and the quality of country governance? Strategic Management J. 32(6):658-681.

Oh C, Oetzel J (2017) Once bitten twice shy? Experience managing violent conflict risk and MNC subsidiary-level investment and expansion. Strategic Management J. forthcoming.

Okhmatovskiy I, David R. (2012) Setting your own standards: Internal corporate governance codes as a response to institutional pressure. Organ. Sci. 23:155-176.

Pacheco D, York J, Hargrave T. (2014) The co-evolution of industries, social movements, and institutions: The case of wind power. Organ. Sci. 25:1609-1632.

Paes W-C, Shaw T (2003) Praetorians or profiteers? The role of entrepreneurial armed forces in CongoKinshasa. Brömmelhörster J, Paes W-C, eds., The Military As an Economic Actor: Soldiers in Business (Palgrave Macmillan, New York), 143-169.

Peng M, Luo Y (2000) Managerial ties and firm performance in a transition economy: The nature of a micro-macro link. Acad. Management J. 43:486-501.

Pfeffer J, Salancik G (2003) The External Control of Organizations: A Resource Dependence Perspective (Stanford University Press, Stanford, CA).

Prada P, Moffett M (2010) Chile aid arrives, amid criticism. The Wall Street Journal, March 2.

Pye L (1961) Armies in the process of political modernization. European J. Sociol. 2(1):82-92.

Rao H, Monin P, Durand R (2003) Institutional change in Toque Ville: Nouvelle cuisine as an identity movement in French gastronomy. Amer. J. Sociol. 108(4):795-843.

Raven B, French J (1958) Legitimate power, coercive power, and observability in social influence. Sociometry 21(2):83-97.

Reno W (1997) African weak states and commercial alliances. African Affairs 96:165-185.

Resende-Santos J (2007) Neorealism States and the Modern Mass Army (Cambridge University Press, Cambridge, UK).

Roubini N (1991) Economic and political determinants of budget deficits in developing countries. J. of International Money and Finance 10:S49-S72.

Rouquié A (1987) The Military and the State in Latin America (Sigmund PE trans.) (University of California Press, Berkeley, CA).

Rowley T (1997) Moving beyond dyadic ties: A network theory of stakeholder influences. Acad. Management Rev. 22(4):887-910.

Rowley T, Behrens D, Krackhardt D (2000) Redundant governance structures: An analysis of structural and relational embeddedness in the steel and semiconductor industries. Strategic Management J. 21(3):369-386.

Russell DE (1974) Rebellion, Revolution, and Armed Force (Academic Press, New York).

Sarkees M, Wayman F (2010) Resort to War: 1816-2007 (CQ Press, Washington, DC). 
Shemo DJ (1996) Oil companies buying an army to ward off rebels in Colombia. New York Times, August 22.

Schneider BR (1991) Politics Within the State: Elite Bureaucrats and Industrial Policy in Authoritarian Brazil (University of Pittsburgh Press, Pittsburgh, PA).

Schneider S (1992) Governmental response to disasters: The conflict between bureaucratic procedures and emergent norms. Public Admin. Rev. 52(2):135-145.

Shils E (1962) The military in the political development of states. Johnson JA, ed. Role of Military in Underdeveloped Countries (Princeton University Press, Princeton, NJ), 7-68.

Siegel J (2007) Contingent political capital and international alliances: Evidence from South Korea. Admin. Sci. Quart. 52:621-666.

Singer D, Bremer S, Stuckey J (1972) Capability distribution, uncertainty, and major power war, 18201965. Russett B, ed. Peace, War, and Numbers (Sage, Beverly Hills, CA), 19-48.

Smallman S (1997) Shady business: Corruption in the Brazilian Army before 1954. Latin Amer. Res. Rev. 32(3):39-62.

Soeters J (2007) Organizations as coercive institutions. Ritzer G, ed., Blackwell Encyclopedia of Sociology (Blackwell, Malden, MA), 3315-3319.

Soule S, Swaminathan A, Tihanyi L (2014) The diffusion of foreign divestment from Burma. Strategic Management J. 35:1032-1052.

Stevens C, Xie E, Peng M (2016) Toward a legitimacy-based view of political risk: The case of Google and Yahoo in China. Strategic Management J. 37:945-963.

Stuart T, Wang Y. (2016) Who cooks the books in China, and does it pay? Evidence from private, hightechnology firms. Strategic Management J. 37: 2658-2676.

Tantalo C, Priem R. (2016) Value creation through stakeholder synergy. Strategic Management J. $37(2): 314-329$.

Tracey P (2012) Religion and organization: A critical review of current trends and future directions. The Acad. Management Annals 6:87-134.

Tsebelis, G (1995) Decision making in political systems: Veto players in presidentialism, parliamentarism, multicameralism and multipartyism. British J. Political Sci. 25:289-325.

Vaaler P, McNamara G (2004) Crisis and competition in expert organizational decision making: Creditrating agencies and their response to turbulence in emerging economies. Organ. Sci. 15:687-703.

Vasi I, King B (2012) Social movements, risk perceptions, and economic outcomes: The effect of primary and secondary stakeholder activism on firms' perceived environmental risk and financial performance. Amer. Soc. Rev. 77:573-596.

Vyas K (2016) China rethinks its alliance with reeling Venezuela. Wall Street Journal, September 11.

Walker E, Rea C (2014) The political mobilization of firms and industries. Annual Rev. of Soc. 40(1): 281-304.

Webb J, Tihanyi L, Ireland R, Sirmon D. 2009. You say illegal, I say legitimate: Entrepreneurship in the informal economy. Acad. Management R. 34(3):492-510.

Wry T, Cobb J, Aldrich H (2013) More than a metaphor: Assessing the historical legacy of resource dependence and its contemporary promise as a theory of environmental complexity. Acad. of Management Annals 7(1):441-488.

York J, Hargrave T, Pacheco D (2016) Converging winds: Logic hybridization in the Colorado wind energy field. Acad. Management J. 59(2):579-610.

Zhang J, Marquis C, Qiao K (2016) Do political connections buffer firms from or bind firms to the government? A study of corporate charitable donations of Chinese firms. Organ. Sci. 27(5):13071324.

Zhu H, Chung C (2014) Portfolios of political ties and business group strategy in emerging economies: Evidence from Taiwan. Admin. Sci. Quart. 59:599-638. 
Table 1. Bivariate Correlations and Descriptive Statistics

\begin{tabular}{|c|c|c|c|c|c|c|c|c|c|c|c|}
\hline & Variable & Mean & Std. Dev. & $\mathbf{0}$ & 1 & 2 & 3 & 4 & 5 & 6 & 7 \\
\hline $\mathbf{0}$ & Failure & 0.312 & 0.463 & 1 & & & & & & & \\
\hline 1 & Military ties & 0.292 & 0.455 & -0.272 & 1 & & & & & & \\
\hline 2 & Political ties & 0.181 & 0.385 & -0.051 & -0.176 & 1 & & & & & \\
\hline 3 & Airline age & 10.745 & 10.969 & -0.158 & 0.204 & 0.141 & 1 & & & & \\
\hline 4 & Airline size & 417.1 & 720.0 & -0.225 & 0.221 & 0.133 & 0.463 & 1 & & & \\
\hline 5 & Foreign investment & 0.177 & 0.382 & 0.052 & -0.066 & 0.016 & -0.020 & 0.166 & 1 & & \\
\hline 6 & Domestic airline & 0.546 & 0.498 & -0.018 & -0.083 & -0.144 & -0.122 & -0.333 & -0.439 & 1 & \\
\hline 7 & State investment & 0.206 & 0.404 & -0.179 & 0.494 & -0.211 & 0.189 & 0.230 & -0.062 & -0.044 & 1 \\
\hline 8 & Airline-sector age & 37.39 & 15.21 & -0.053 & 0.052 & -0.127 & 0.369 & 0.201 & -0.370 & 0.134 & 0.103 \\
\hline 9 & Airline-sector density & 6.584 & 4.814 & 0.062 & -0.142 & -0.107 & -0.126 & -0.167 & -0.283 & 0.503 & -0.135 \\
\hline 10 & Armed conflict & 0.548 & 1.381 & 0.056 & -0.107 & -0.070 & 0.040 & 0.030 & -0.033 & 0.041 & 0.002 \\
\hline 11 & Country fiscal budget balance / 10,000 & 0.208 & 0.713 & -0.024 & 0.009 & -0.027 & 0.024 & 0.063 & -0.050 & 0.040 & -0.029 \\
\hline 12 & Country GDP per capita & 3912 & 2201 & -0.079 & 0.111 & -0.090 & 0.186 & 0.165 & -0.129 & -0.046 & 0.055 \\
\hline 13 & Country population (millions) & 23.58 & 24.66 & -0.185 & -0.182 & 0.106 & 0.168 & 0.106 & -0.173 & 0.236 & -0.152 \\
\hline 14 & Change in country population & 0.023 & 0.011 & 0.042 & -0.027 & -0.019 & 0.066 & 0.118 & 0.022 & -0.029 & -0.090 \\
\hline 15 & Declining economic environment & -0.104 & 0.111 & 0.058 & -0.007 & 0.061 & -0.003 & -0.038 & 0.098 & -0.063 & 0.011 \\
\hline 16 & Government revolutions & 0.087 & 0.302 & 0.034 & -0.002 & -0.012 & -0.010 & -0.008 & 0.025 & 0.007 & 0.019 \\
\hline 17 & High political effectiveness & 0.248 & 0.432 & -0.053 & 0.078 & 0.067 & -0.010 & 0.070 & -0.065 & -0.099 & -0.089 \\
\hline 18 & Political constraint & 0.182 & 0.218 & 0.013 & -0.063 & 0.025 & 0.027 & 0.102 & -0.056 & -0.023 & -0.112 \\
\hline 19 & Polity index & 0.165 & 6.193 & 0.086 & -0.086 & -0.046 & 0.014 & 0.124 & -0.028 & -0.025 & -0.156 \\
\hline 20 & Primary energy consumption & 24151 & 38350 & -0.098 & -0.114 & -0.073 & 0.232 & 0.234 & -0.230 & 0.190 & -0.103 \\
\hline 21 & Ratio of defense to government expenditures & 178 & 72 & -0.042 & -0.028 & 0.058 & -0.139 & -0.104 & -0.026 & 0.120 & 0.011 \\
\hline
\end{tabular}

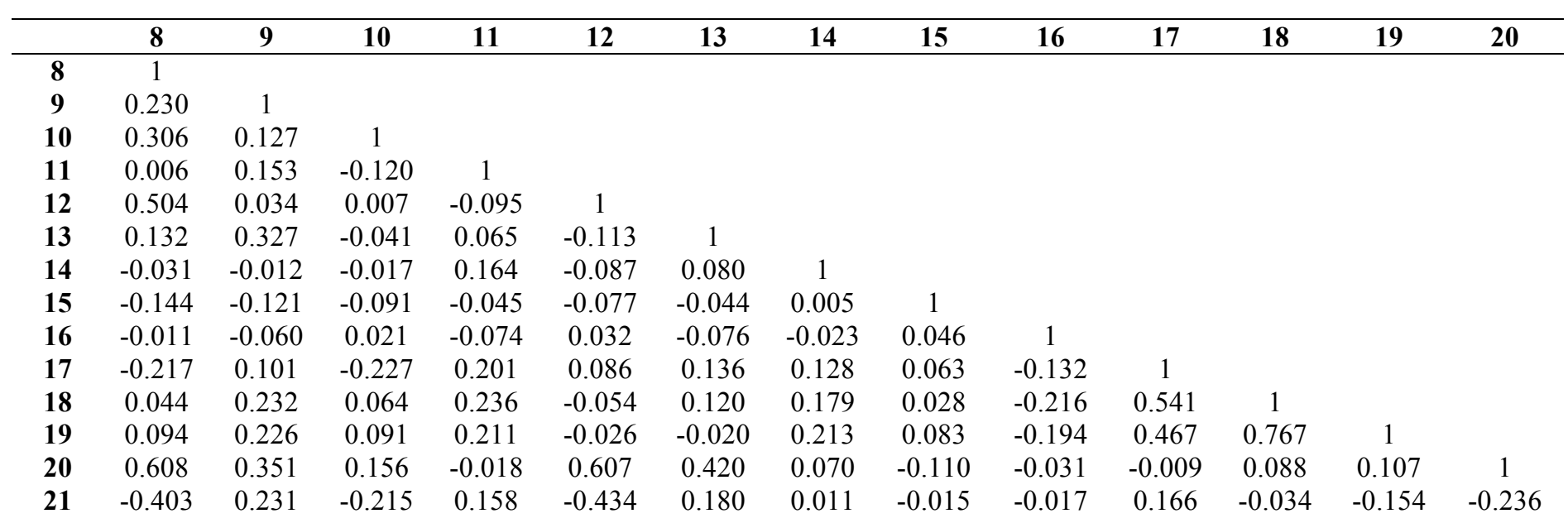


Table 2. Event-History Model Predicting Failure of Ventures

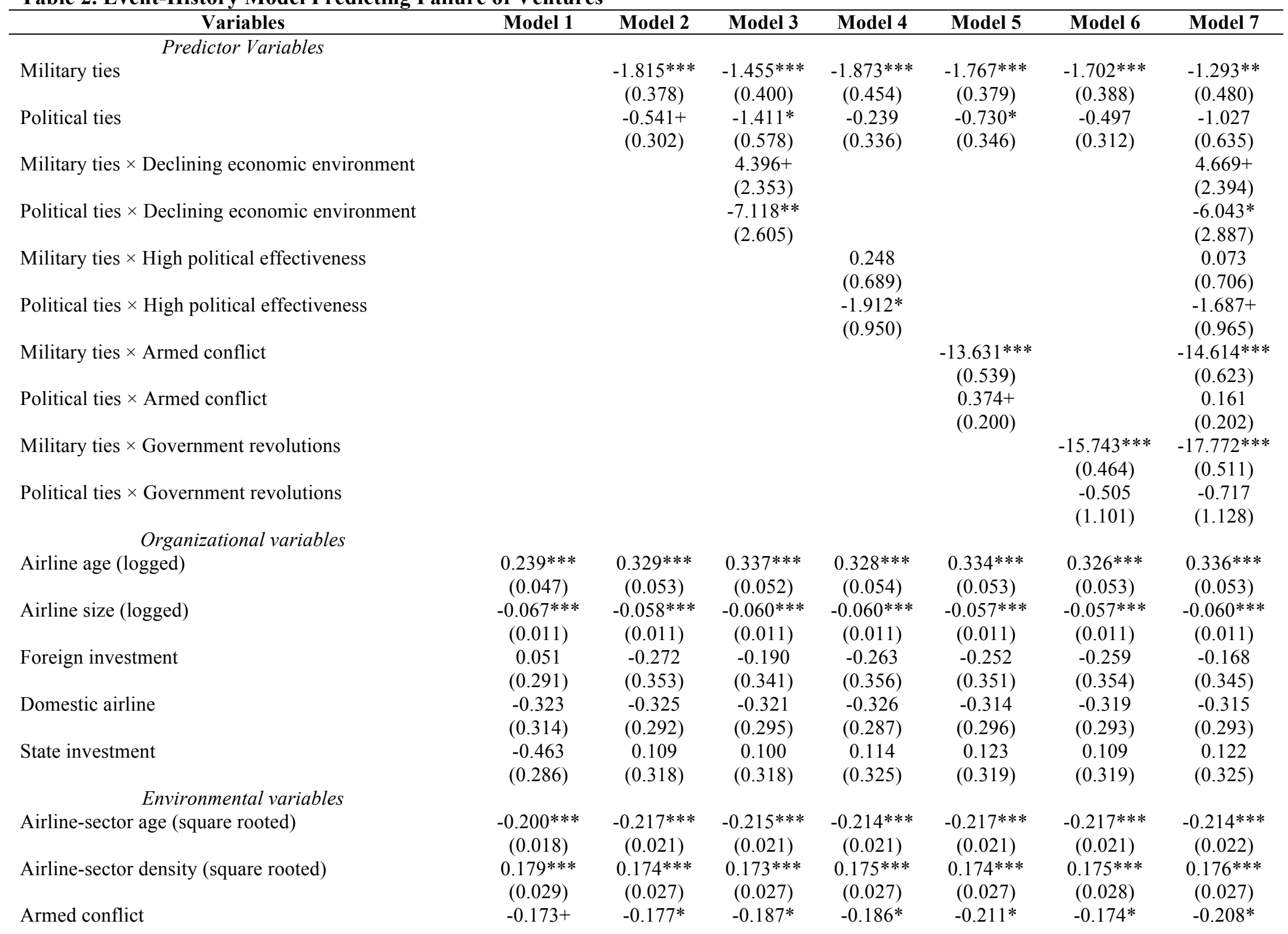




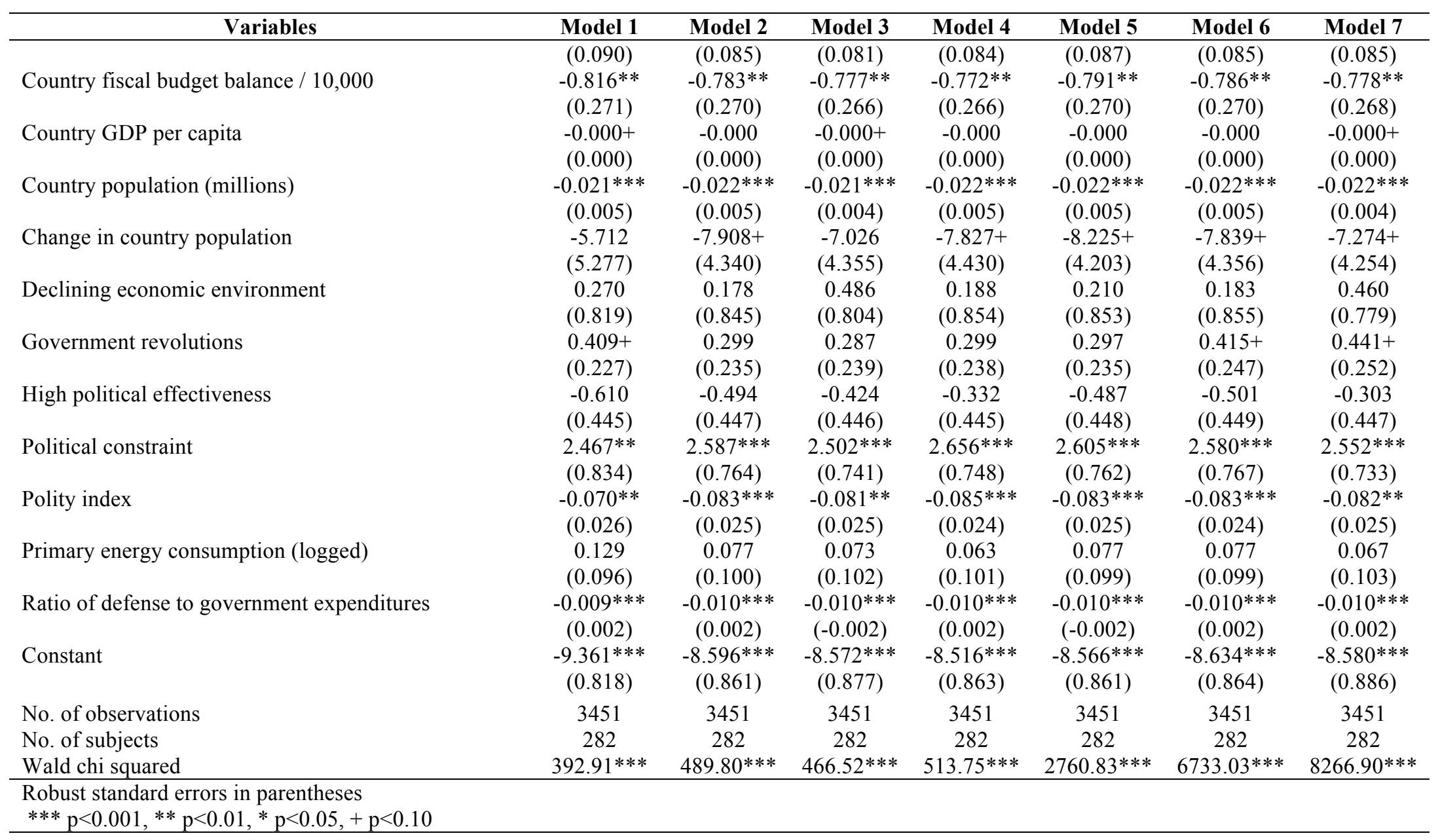


APPENDIX

Figure 1: Two-Way Interaction of Political Ties and Declining Economic Environment

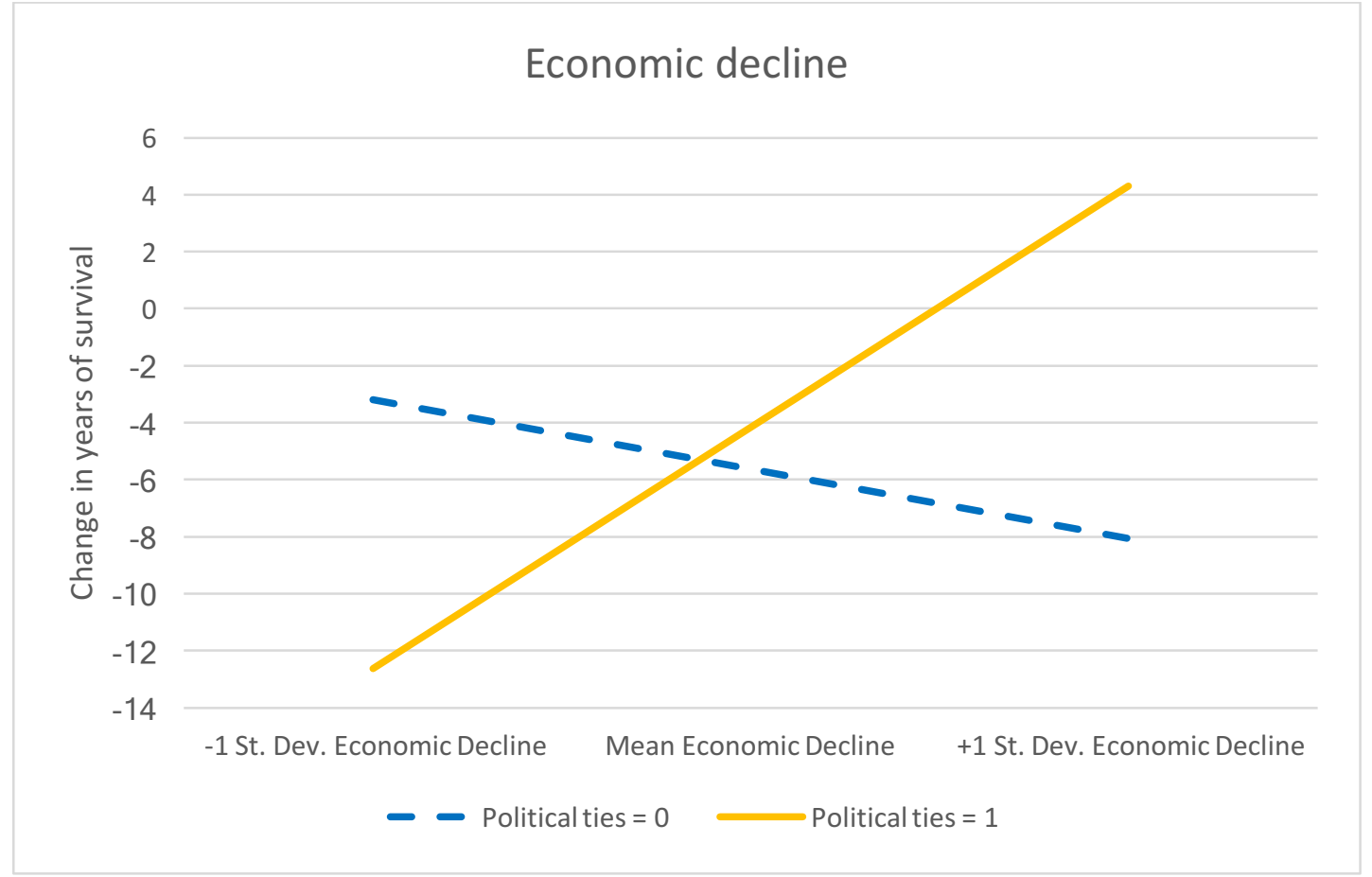

Figure 2: Two-Way Interaction of Political Ties and Political Effectiveness

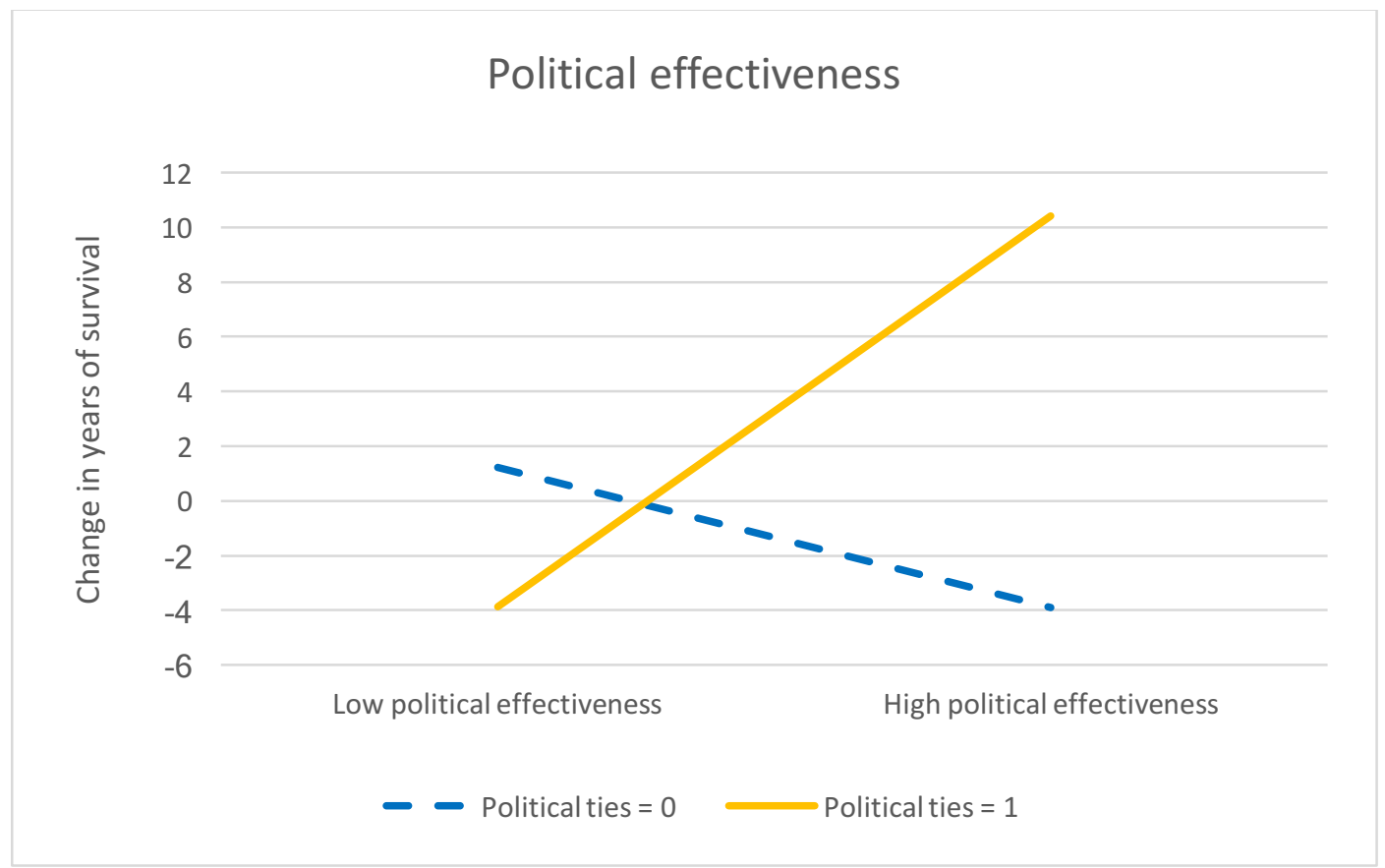


Figure 3: Two-Way Interaction of Military Ties and Armed Conflict

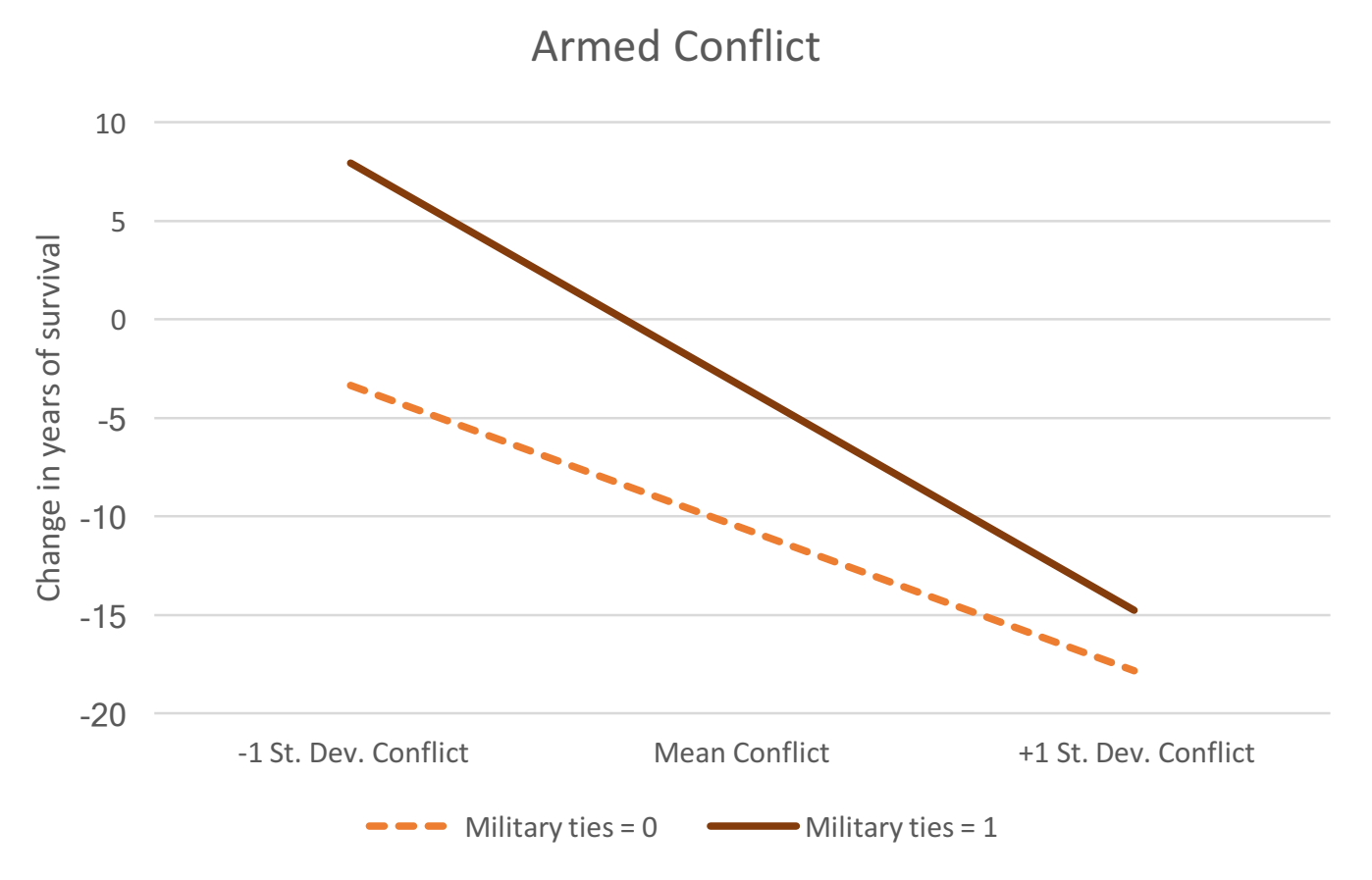

Figure 4: Two-Way Interaction of Military Ties and Revolutions

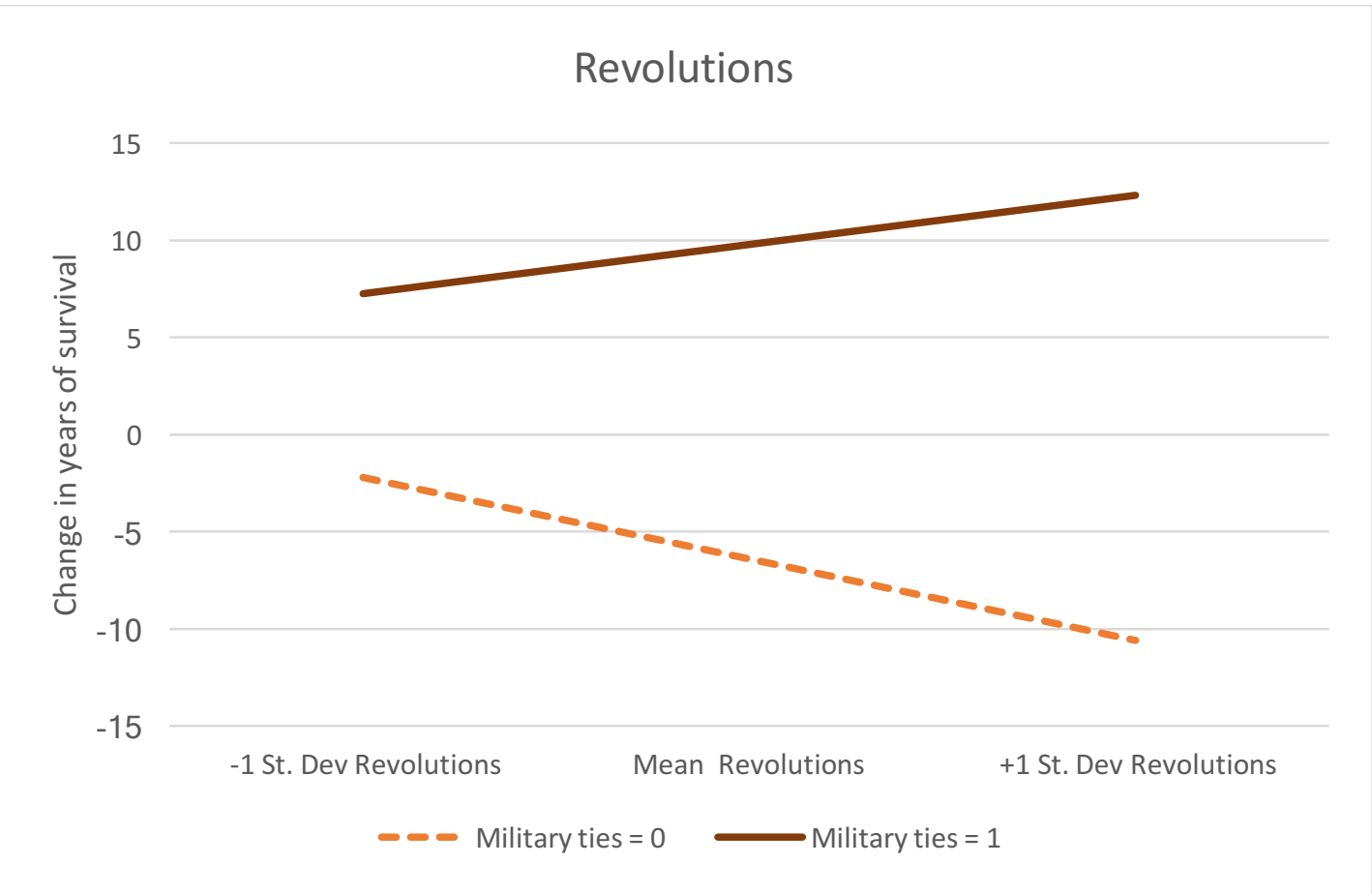


Table A1: First-stage Probit Model Predicting Military Ties at Venture Founding

\begin{tabular}{|c|c|}
\hline Variables & $\begin{array}{c}\text { Failure } \\
\text { Model } 1\end{array}$ \\
\hline \multicolumn{2}{|l|}{ Instrumental Variables } \\
\hline Military size & $\begin{array}{c}0.001 * * * \\
(0.000)\end{array}$ \\
\hline Percentage of workers in industrial production & $\begin{array}{c}-0.001 * * * \\
(0.000)\end{array}$ \\
\hline \multicolumn{2}{|l|}{ Organizational variables } \\
\hline Political ties & $\begin{array}{c}-0.128 * * * \\
(0.018)\end{array}$ \\
\hline Airline age & $\begin{array}{c}0.005^{* * *} * \\
(0.001)\end{array}$ \\
\hline Airline size & $\begin{array}{c}0.000 * * * \\
(0.000)\end{array}$ \\
\hline Foreign ownership & $\begin{array}{c}-0.141 * * * \\
(0.021)\end{array}$ \\
\hline Domestic airline & $\begin{array}{c}-0.024 \\
(0.017)\end{array}$ \\
\hline State investment & $\begin{array}{c}0.441 * * * \\
(0.018)\end{array}$ \\
\hline \multicolumn{2}{|l|}{ Environmental variables } \\
\hline Airline-sector age & $\begin{array}{c}-0.000 \\
(0.001)\end{array}$ \\
\hline Airline-sector density & $\begin{array}{l}0.004+ \\
(0.002)\end{array}$ \\
\hline Armed conflict & $\begin{array}{c}-0.021 * * * \\
(0.005)\end{array}$ \\
\hline Country fiscal budget balance / 10,000 & $\begin{array}{c}-0.006 \\
(0.009)\end{array}$ \\
\hline Country GDP in billions & $\begin{array}{c}-0.001 * * * \\
(0.000)\end{array}$ \\
\hline Country population (logged) & $\begin{array}{c}-0.137 * * * \\
(0.015)\end{array}$ \\
\hline Political institution stability & $\begin{array}{c}0.000 \\
(0.000)\end{array}$ \\
\hline Government revolutions & $\begin{array}{l}-0.012 \\
(0.021)\end{array}$ \\
\hline Political effectiveness & $\begin{array}{c}0.000 \\
(0.009)\end{array}$ \\
\hline Political constraint & $\begin{array}{c}-0.072 \\
(0.046)\end{array}$ \\
\hline Total trade per capita & $\begin{array}{c}55.687 * * * \\
(6.481)\end{array}$ \\
\hline Trade balance / 1000 & $\begin{array}{c}0.472 * * * \\
(0.066)\end{array}$ \\
\hline Constant & $\begin{array}{c}2.519 * * * \\
(0.247)\end{array}$ \\
\hline $\begin{array}{l}\text { Standard errors in parentheses } \\
* * * \mathrm{p}<0.001, * * \mathrm{p}<0.01, * \mathrm{p}<0.05,+\mathrm{p}<0.10\end{array}$ & \\
\hline
\end{tabular}


Table A2: Second-stage Probit of Impact of Military Ties on Venture Failure

\begin{tabular}{|c|c|}
\hline Variables & Model 1 \\
\hline \multicolumn{2}{|c|}{ Organizational variables } \\
\hline Military ties & $\begin{array}{c}-1.756 * * \\
(0.592)\end{array}$ \\
\hline Political ties & $\begin{array}{c}-0.407 * * \\
(0.125)\end{array}$ \\
\hline Airline age & $\begin{array}{c}0.001 \\
(0.007)\end{array}$ \\
\hline Airline size & $\begin{array}{c}-0.000+ \\
(0.000)\end{array}$ \\
\hline Foreign ownership & $\begin{array}{l}-0.150 \\
(0.162)\end{array}$ \\
\hline Domestic airline & $\begin{array}{l}-0.146 \\
(0.099)\end{array}$ \\
\hline State investment & $\begin{array}{l}0.527+ \\
(0.313)\end{array}$ \\
\hline \multicolumn{2}{|l|}{ Environmental variables } \\
\hline Airline-sector age & $\begin{array}{l}-0.001 \\
(0.004)\end{array}$ \\
\hline Airline-sector density & $\begin{array}{l}0.025^{*} \\
(0.011)\end{array}$ \\
\hline Armed conflict & $\begin{array}{c}-0.132 * * * \\
(0.033)\end{array}$ \\
\hline Country fiscal budget balance / 10,000 & $\begin{array}{c}-0.300 * * \\
(0.107)\end{array}$ \\
\hline Country GDP in billions & $\begin{array}{l}-0.002 * \\
(0.001)\end{array}$ \\
\hline Country population (logged) & $\begin{array}{l}-0.117 \\
(0.094)\end{array}$ \\
\hline Political institution stability & $\begin{array}{l}0.003 * \\
(0.001)\end{array}$ \\
\hline Government revolutions & $\begin{array}{c}0.009 \\
(0.118)\end{array}$ \\
\hline Political effectiveness & $\begin{array}{c}-0.115+ \\
(0.060)\end{array}$ \\
\hline Political constraint & $\begin{array}{c}0.009 \\
(0.277)\end{array}$ \\
\hline Total trade per capita & $\begin{array}{c}38.662 \\
(79.890)\end{array}$ \\
\hline Trade balance / 1000 & $\begin{array}{c}0.041 \\
(0.786)\end{array}$ \\
\hline Constant & $\begin{array}{c}1.317 \\
(1.665)\end{array}$ \\
\hline$N$ & 3520 \\
\hline Wald chi squared & $128.67 * * *$ \\
\hline $\begin{array}{l}\text { Standard errors in parentheses } \\
* * * \mathrm{p}<0.001, * * \mathrm{p}<0.01, * \mathrm{p}<0.05,+\mathrm{p}\end{array}$ & \\
\hline
\end{tabular}


Table A2: Event-History Model Predicting Failure of Ventures with Three-way Interactions

\begin{tabular}{|c|c|c|c|c|c|}
\hline Variables & Model 8 & Model 9 & Model 10 & Model 11 & Model 12 \\
\hline \multicolumn{6}{|l|}{ Predictor Variables } \\
\hline Military ties & $\begin{array}{c}-1.475^{* *} \\
(0.455)\end{array}$ & $\begin{array}{c}-1.856^{* * *} \\
(0.407)\end{array}$ & $\begin{array}{c}-1.798 * * * \\
(0.381)\end{array}$ & $\begin{array}{c}-1.702 * * * \\
(0.388)\end{array}$ & $\begin{array}{c}-1.607 * * * \\
(0.445)\end{array}$ \\
\hline Political ties & $\begin{array}{l}-0.834^{*} \\
(0.345)\end{array}$ & $\begin{array}{l}-0.237 \\
(0.332)\end{array}$ & $\begin{array}{l}-0.712^{*} \\
(0.341)\end{array}$ & $\begin{array}{l}-0.497 \\
(0.312)\end{array}$ & $\begin{array}{l}-0.881+ \\
(0.455)\end{array}$ \\
\hline \multicolumn{6}{|l|}{ Military ties X Declining economic environment } \\
\hline X Airline-sector density & $\begin{array}{c}0.862 \\
(1.070)\end{array}$ & & & & $\begin{array}{c}0.820 \\
(0.612)\end{array}$ \\
\hline \multicolumn{6}{|l|}{ Political ties X Declining economic environment } \\
\hline X Airline-sector density & $\begin{array}{l}-0.353^{* * *} \\
(0.090)\end{array}$ & & & & $\begin{array}{c}-0.667 * * \\
(0.231)\end{array}$ \\
\hline \multicolumn{6}{|l|}{ Military ties X High political effectiveness X } \\
\hline Airline-sector density & & $\begin{array}{c}0.022 \\
(0.047)\end{array}$ & & & $\begin{array}{c}0.112 \\
(0.081)\end{array}$ \\
\hline \multicolumn{6}{|l|}{ Political ties X High political effectiveness X } \\
\hline Airline-sector density & & $\begin{array}{l}-0.490^{*} \\
(0.241)\end{array}$ & & & $\begin{array}{l}-0.380^{*} \\
(0.193)\end{array}$ \\
\hline $\begin{array}{l}\text { Military ties X Armed conflict X Domestic } \\
\text { airline }\end{array}$ & & & $\begin{array}{c}-11.665^{* * *} \\
(0.782)\end{array}$ & & $\begin{array}{l}-10.965 * * * \\
(0.894)\end{array}$ \\
\hline $\begin{array}{l}\text { Political ties X Armed conflict X Domestic } \\
\text { airline }\end{array}$ & & & $\begin{array}{l}0.464^{*} \\
(0.207)\end{array}$ & & $\begin{array}{c}0.100 \\
(0.238)\end{array}$ \\
\hline \multicolumn{6}{|l|}{ Military ties X Government revolutions X } \\
\hline Domestic airline & & & & $\begin{array}{l}-15.743 * * * \\
(0.464)\end{array}$ & $\begin{array}{l}-14.462 * * * \\
(0.515)\end{array}$ \\
\hline \multicolumn{6}{|l|}{ Political ties X Government revolutions X } \\
\hline Domestic airline & & & & $\begin{array}{l}-0.505 \\
(1.101)\end{array}$ & $\begin{array}{c}0.324 \\
(1.122)\end{array}$ \\
\hline \multicolumn{6}{|l|}{ Organizational variables } \\
\hline Airline age (logged) & $\begin{array}{c}0.334 * * * \\
(0.052)\end{array}$ & $\begin{array}{c}0.329 * * * \\
(0.054)\end{array}$ & $\begin{array}{c}0.336 * * * \\
(0.053)\end{array}$ & $\begin{array}{c}0.326 * * * \\
(0.053)\end{array}$ & $\begin{array}{c}0.335 * * * \\
(0.054)\end{array}$ \\
\hline Airline size (logged) & $\begin{array}{l}-0.060 * * * \\
(0.011)\end{array}$ & $\begin{array}{l}-0.060 * * * \\
(0.011)\end{array}$ & $\begin{array}{c}-0.057 * * * \\
(0.011)\end{array}$ & $\begin{array}{l}-0.057 * * * \\
(0.011)\end{array}$ & $\begin{array}{c}-0.060 * * * \\
(0.011)\end{array}$ \\
\hline Foreign investment & $\begin{array}{l}-0.236 \\
(0.347)\end{array}$ & $\begin{array}{l}-0.277 \\
(0.355)\end{array}$ & $\begin{array}{l}-0.278 \\
(0.352)\end{array}$ & $\begin{array}{l}-0.259 \\
(0.354)\end{array}$ & $\begin{array}{l}-0.255 \\
(0.343)\end{array}$ \\
\hline Domestic airline & $\begin{array}{l}-0.334 \\
(0.294)\end{array}$ & $\begin{array}{l}-0.328 \\
(0.286)\end{array}$ & $\begin{array}{l}-0.348 \\
(0.298)\end{array}$ & $\begin{array}{l}-0.319 \\
(0.293)\end{array}$ & $\begin{array}{l}-0.365 \\
(0.284)\end{array}$ \\
\hline State investment & $\begin{array}{c}0.086 \\
(0.323)\end{array}$ & $\begin{array}{c}0.124 \\
(0.323)\end{array}$ & $\begin{array}{c}0.113 \\
(0.321)\end{array}$ & $\begin{array}{c}0.109 \\
(0.319)\end{array}$ & $\begin{array}{c}0.127 \\
(0.330)\end{array}$ \\
\hline Environmental variables & & & & & \\
\hline Airline-sector age (square rooted) & $\begin{array}{c}-0.217 * * * \\
(0.021)\end{array}$ & $\begin{array}{c}-0.215^{* * *} \\
(0.021)\end{array}$ & $\begin{array}{c}-0.218^{* * *} \\
(0.021)\end{array}$ & $\begin{array}{c}-0.217 * * * \\
(0.021)\end{array}$ & $\begin{array}{c}-0.219 * * * \\
(0.021)\end{array}$ \\
\hline Airline-sector density (square rooted) & $\begin{array}{c}0.170 * * * \\
(0.027)\end{array}$ & $\begin{array}{c}0.174 * * * \\
(0.028)\end{array}$ & $\begin{array}{c}0.174 * * * \\
(0.027)\end{array}$ & $\begin{array}{c}0.175^{* * * *} \\
(0.028)\end{array}$ & $\begin{array}{c}0.172 * * * \\
(0.027)\end{array}$ \\
\hline Armed conflict & $\begin{array}{l}-0.180^{*} \\
(0.083)\end{array}$ & $\begin{array}{l}-0.186^{*} \\
(0.085)\end{array}$ & $\begin{array}{c}-0.212^{*} \\
(0.086)\end{array}$ & $\begin{array}{l}-0.174^{*} \\
(0.085)\end{array}$ & $\begin{array}{l}-0.202 * \\
(0.082)\end{array}$ \\
\hline Country fiscal budget balance / 10,000 & $\begin{array}{c}-0.779 * * \\
(0.272)\end{array}$ & $\begin{array}{c}-0.770 * * \\
(0.264)\end{array}$ & $\begin{array}{c}-0.790 * * \\
(0.271)\end{array}$ & $\begin{array}{c}-0.786^{* *} \\
(0.270)\end{array}$ & $\begin{array}{c}-0.763 * * \\
(0.268)\end{array}$ \\
\hline Country GDP per capita & $\begin{array}{l}-0.000 \\
(0.000)\end{array}$ & $\begin{array}{l}-0.000 \\
(0.000)\end{array}$ & $\begin{array}{l}-0.000 \\
(0.000)\end{array}$ & $\begin{array}{l}-0.000 \\
(0.000)\end{array}$ & $\begin{array}{c}-0.000+ \\
(0.000)\end{array}$ \\
\hline Country population (square rooted) & $\begin{array}{c}-0.022 * * * \\
(0.004)\end{array}$ & $\begin{array}{c}-0.022 * * * \\
(0.005)\end{array}$ & $\begin{array}{c}-0.022 * * * \\
(0.005)\end{array}$ & $\begin{array}{c}-0.022 * * * \\
(0.005)\end{array}$ & $\begin{array}{c}-0.022 * * * \\
(0.004)\end{array}$ \\
\hline
\end{tabular}




\begin{tabular}{lccccc}
\hline \multicolumn{1}{c}{ Variables } & Model 8 & Model 9 & Model 10 & Model 11 & Model 12 \\
\hline Change in country population & $-7.892+$ & $-7.952+$ & $-8.231^{*}$ & $-7.839+$ & $-8.142+$ \\
& $(4.293)$ & $(4.451)$ & $(4.183)$ & $(4.356)$ & $(4.165)$ \\
Declining economic environment & 0.156 & 0.196 & 0.226 & 0.183 & 0.348 \\
& $(0.826)$ & $(0.857)$ & $(0.866)$ & $(0.855)$ & $(0.803)$ \\
Government revolutions & 0.302 & 0.302 & 0.303 & $0.415+$ & 0.329 \\
& $(0.234)$ & $(0.237)$ & $(0.235)$ & $(0.247)$ & $(0.239)$ \\
High political effectiveness & -0.495 & -0.337 & -0.495 & -0.501 & -0.369 \\
& $(0.448)$ & $(0.428)$ & $(0.448)$ & $(0.449)$ & $(0.436)$ \\
Political constraint & $2.542^{* * *}$ & $2.666^{* * *}$ & $2.613 * * *$ & $2.580^{* * *}$ & $2.508^{* * * *}$ \\
& $(0.753)$ & $(0.749)$ & $(0.766)$ & $(0.767)$ & $(0.706)$ \\
Polity index & $-0.082^{* * *}$ & $-0.085^{* * *}$ & $-0.084^{* * *}$ & $-0.083^{* * *}$ & $-0.084^{* * *}$ \\
& $(0.025)$ & $(0.024)$ & $(0.025)$ & $(0.024)$ & $(0.024)$ \\
Primary energy consumption (logged) & 0.084 & 0.070 & 0.081 & 0.077 & 0.086 \\
& $(0.101)$ & $(0.099)$ & $(0.100)$ & $(0.099)$ & $(0.103)$ \\
Ratio of defense to government expenditures & $-0.010^{* * *}$ & $-0.010^{* * *}$ & $-0.010^{* * *}$ & $-0.010^{* * *}$ & $-0.010^{* * *}$ \\
& $(0.002)$ & $(0.002)$ & $(0.002)$ & $(0.002)$ & $(0.002)$ \\
Constant & $-8.600^{* * *}$ & $-8.560^{* * *}$ & $-8.580^{* * *}$ & $-8.634^{* * *}$ & $-8.566^{* * *}$ \\
& $(0.896)$ & $(0.856)$ & $(0.865)$ & $(0.864)$ & $(0.883)$ \\
No. of observations & 3451 & 3451 & 3451 & 3451 & 3451 \\
No. of subjects & 282 & 282 & 282 & 282 & 282 \\
Wald chi squared & $479.38^{* * *}$ & $529.96^{* * *}$ & $1781.95 * * *$ & $6733.03 * * *$ & $6313.78^{* * *}$ \\
\hline Robust standard errors in parentheses & & & & & \\
$* * * \mathrm{p}<0.001, * * \mathrm{p}<0.01, * \mathrm{p}<0.05,+\mathrm{p}<0.10$ & & & & & \\
\hline
\end{tabular}

